NBER WORKING PAPER SERIES

THE LABOR SUPPLY OF UNDOCUMENTED IMMIGRANTS

\author{
George J. Borjas \\ Working Paper 22102 \\ http://www.nber.org/papers/w22102 \\ NATIONAL BUREAU OF ECONOMIC RESEARCH \\ 1050 Massachusetts Avenue \\ Cambridge, MA 02138 \\ March 2016
}

This research was supported by the U.S. Social Security Administration through grant \#RRC08098400-07 to the National Bureau of Economic Research as part of the SSA Retirement Research Consortium. The findings and conclusions expressed are solely those of the author(s) and do not represent the views of SSA, any agency of the Federal Government, or the NBER. I am particularly grateful to Mark Lopez and Jeffrey Passel of the Pew Research Center for their generosity in sharing data files. I have also benefited from comments by Amy Finkelstein, Jeffrey Brown, Austan Goolsbee, Lynn Fisher, Stephen Goss, and Sven Sinclair. The views expressed herein are those of the author and do not necessarily reflect the views of the National Bureau of Economic Research.

NBER working papers are circulated for discussion and comment purposes. They have not been peer-reviewed or been subject to the review by the NBER Board of Directors that accompanies official NBER publications.

(C) 2016 by George J. Borjas. All rights reserved. Short sections of text, not to exceed two paragraphs, may be quoted without explicit permission provided that full credit, including () notice, is given to the source. 
The Labor Supply of Undocumented Immigrants

George J. Borjas

NBER Working Paper No. 22102

March 2016

JEL No. J22,J6

\begin{abstract}
$\underline{\text { ABSTRACT }}$
The Department of Homeland Security estimates that 11.4 million undocumented persons reside in the United States. Congress and President Obama are considering a number of proposals to regularize the status of the undocumented population and provide a "path to citizenship." Any future change in the immigration status of this group is bound to have significant effects on the labor market, on the number of persons that qualify for various government-provided benefits, on the timing of retirement, on the size of the population receiving Social Security benefits, and on the funding of almost all of these government programs. This paper provides a comprehensive empirical study of the labor supply behavior of undocumented immigrants in the United States. Using newly developed methods that attempt to identify undocumented status for foreign-born persons sampled in the Current Population Surveys, the empirical analysis documents a number of findings, including the fact that the work propensity of undocumented men is much larger than that of other groups in the population; that this gap has grown over the past two decades; and that the labor supply elasticity of undocumented men is very close to zero, suggesting that their labor supply is almost perfectly inelastic.
\end{abstract}

George J. Borjas

Harvard Kennedy School

79 JFK Street

Cambridge, MA 02138

and NBER

gborjas@harvard.edu 


\title{
The Labor Supply of Undocumented Immigrants:
}

\author{
George J. Borjas
}

\section{Introduction}

The Department of Homeland Security (DHS) estimates that 11.4 million undocumented persons reside in the United States (as of January 2012). Congress is considering a number of proposals to regularize the status of the undocumented population and provide a "path to citizenship," while President Obama has issued executive orders that grant some form of amnesty to about half of this population.

Given the size of the undocumented population, any future change in the immigration status of this group is bound to have significant effects on the labor market, on the number of persons that qualify for various government-provided benefits, on the timing of retirement, on the size of the population receiving Social Security benefits, and on the funding of almost all of these government programs.

Any evaluation that attempts to predict the impact of the regularization of immigration status for the undocumented population on the inflows and outflows of funds into any government program immediately runs into a major roadblock: It is difficult to conduct such a calculation because we know little about the economic status and well-being of the 11.4 million undocumented persons in the United States. We do not have detailed information on the individual employment histories (so, for example, we do not know how many would potentially meet the 40-quarter eligibility requirement for Social Security). Similarly, we lack information on the shape of the age-earnings profiles, on the individual histories of contributions to various government programs, or on how those earnings and contributions would change if the undocumented worker's status were regularized. ${ }^{1}$ We also have no basis for predicting how the employment decisions of the undocumented population would change after their status is regularized. For example, the regularization of status might increase the average wage in the undocumented population simply because undocumented workers may then choose from a much

\footnotetext{
${ }^{1}$ The Social Security Administration, however, does have information on the total amount of Social Security taxes paid where the worker's name and Social Security number do not match, and most of those taxes are probably paid by workers who are not authorized to work in the United States.
} 
wider set of employment options. But how would these wage change affect labor supply over the life cycle? How would the wage changes affect retirement choices?

This paper represents a first attempt at providing some of the requisite background information involved in conducting any such future evaluation. ${ }^{2}$ In particular, the paper provides a comprehensive empirical study of the labor supply behavior of undocumented immigrants in the United States.

The empirical analysis of the labor supply of a hard-to-detect and hard-to-identify population is made possible by the fact that some researchers have developed methods that attempt to identify the undocumented status of foreign-born persons in micro data sets, such as the American Community Surveys or the Current Population Surveys. These attempts build on the framework first developed by Passel and Warren (1987) that attempt to estimate the size of the undocumented population. The Passel-Warren methodology, in fact, underlies the "official” estimates of this population reported by DHS.

Jeffrey Passel (now at the Pew Research Center) and various colleagues have continued to improve and extend the initial methodology over the past two decades. This additional work has led to the creation of some micro-level CPS files that contain a variable indicating if a foreign-born person is “likely authorized” or “likely unauthorized.” I have been granted access to the 2012-2013 Annual Socioeconomic and Economic Supplements (ASEC) created by the Pew Research Center that contains the undocumented status identifier. After carefully examining the Pew methodology, I have adapted and extended their approach so that I could create an undocumented status identifier in all the ASEC files where foreign-born status is reported (i.e., all the ASEC files from 1994 to 2014). This extension of the Pew approach yields a time series of micro data that allows an examination of the labor supply of undocumented immigrants, as well as a study of the factors that distinguish the trends in the labor supply of this group from those of the native-born and of legal immigrants.

The analysis of the various CPS cross-sections yields a number of important findings:

2 Goss et al. (2013) report calculations linking immigration and the Trust Funds of the Social Security System made by the Actuaries of the Social Security Administration. See also Bohn, Lofstrom, and Raphael (2014) and Bohn and Lofstrom (2012) for related work. 
1. The labor supply of undocumented immigrant men, as measured by the probability of employment during the CPS reference week, is far higher for undocumented immigrant men than for legal immigrant men, which in turn is much higher than for native men.

2. The probability that undocumented immigrant women work is lower than the probability that legal immigrant women work, which in turn is lower than the probability that native women work.

3. The already large differences in employment probabilities between undocumented men and native men widens dramatically after controlling for differences in skills and other socioeconomic characteristics. In contrast, the difference in employment probability between undocumented women and native women narrows after such controls.

4. The absolute and relative employment rates of undocumented men rose dramatically during the 1994-2014 period. In fact, the employment gap between undocumented men and native men widened by perhaps 10 percentage points during this period. The relative employment rates of undocumented women also rose, but at a much slower rate.

5. The labor supply of undocumented men and women is less responsive to wage changes than that of legal immigrants, which in turn is less responsive that that of native persons. The lack of responsiveness to wage changes in the undocumented population is particularly stark in the sample of men: It is easy to infer that the labor supply of undocumented men is perfectly inelastic.

This diverse set of findings helps to provide a foundation upon which an eventual assessment of the various regularization proposals can be based. It is important to acknowledge at the outset, however, that the robustness of the evidence depends on the validity of the procedure used to impute undocumented status at the micro level. As a result, the type of empirical analysis that is currently possible to document the economic status of undocumented workers is inevitably subject to various types of unknowable and non-classical measurement errors. Nevertheless, any assessment of regularization proposals will require that much more be known about the economic life cycle of the undocumented population in the United States. As the analysis reported in this paper suggests, a more systematic application of the methods that can be used for identifying undocumented status in micro data sets may help provide a unique opportunity for such an assessment to begin. 


\section{Counting and Identifying Undocumented Immigrants}

The statutes regulating legal immigration to the United States have not changed in significant ways since 1965. The 1965 Amendments to the Immigration and Nationality Act introduced a "family preference” system that favors visa applicants who already have relatives residing in the United States (as either citizens or permanent residents). The 1965 Amendments also allocated a relatively small number of visas to persons who apply to enter the United States for employment purposes. Partly because of the numerical statutory limits in immigration law, the number of legal immigrants entering the United States has hovered around 1 million persons per year for over a decade, and more than two-thirds of these immigrants are granted entry visas under the family preference system.

Despite the relative uniformity in the statutes that regulate legal immigration since 1965, a new development has become increasingly more important in the past few decades: the illegal entry of persons into the country. The initial flow of Mexican undocumented immigrants began soon after the discontinuation of the bracero program in the 1960s. ${ }^{3}$ The continuation and growth in undocumented immigration in the 1970s and 1980s led to the enactment of the Immigration Reform and Control Act (IRCA) in 1986, a statute that granted amnesty to 2.7 million persons and that made it illegal (for the first time) for employers to knowingly hire undocumented immigrants.

The Department of Homeland Security (DHS) publishes annual estimates of the size of the undocumented population (Hoefer, Rytina and Baker, 2012). As of January 2012 (the last time that DHS made such a calculation), there were 11.4 million undocumented immigrants residing in the country, a number that (again according to DHS estimates) has held relatively steady since January 2005.

The "residual" methodology used by the DHS to estimate the size of the undocumented population was introduced by Warren and Passel (1987) and is easy to describe. The first step in the calculation involves estimating how many legal immigrants should reside in the United States at a point in time. Over the years, the DHS and its precursor (the Immigration and Naturalization Service) have kept track of the number of legal immigrants admitted to the country (i.e., the number of “green cards” granted to foreign-born persons each year). We also

\footnotetext{
3 The bracero program allowed some Mexicans to enter the United States temporarily and work in the agricultural sector. The program was discontinued in 1964.
} 
"know" how many foreign-born persons live in the United States temporarily (e.g., foreign students, business visitors, diplomats, etc.). These data allow us to apply mortality tables to the cumulative count of green cards distributed and predict how many legal immigrants should be alive and residing in the United States at any given point in time.

At the same time, many government surveys, including the decadal censuses, the American Community Surveys (ACS), and the Current Population Surveys (CPS), periodically sample the U.S. population and specifically ask where each person was born. These surveys provide estimates of how many foreign-born people are actually living in the country. In rough terms, the residual difference between the number of foreign-born persons who are actually living in the United States and the number of legal immigrants who should be living in the United States is the Warren-Passel (and now “official” DHS) estimate of the number of undocumented persons.

It is obvious that the residual methodology faces from one important obstacle. The enumerations in the decadal censuses or the ACS miss many people whenever the enumerators go out and attempt to count (or sample) the population. Some of the people that the enumerators miss are undocumented immigrants who wish to avoid being detected. To calculate an estimate of the size of the undocumented population, therefore, the Warren-Passel methodology must make an assumption about the undercount rate. The DHS uses the assumption that the government enumerators miss 10 percent of the undocumented immigrants (Baker and Rytina, 2013, p. 6).

Jeffrey Passel, who was a statistician with the Bureau of the Census at the time that he and Robert Warren developed the residual methodology, has continued working on the identification and enumeration of undocumented immigrants over the past two decades. As a result of these efforts, Passell—and various colleagues at the Pew Research Center-have now developed a comparable methodology that attempts to identify the undocumented immigrants at the individual level in survey data. Specifically, this work attempts to identify which of the foreign-born persons sampled in a microdata file are legal immigrants and which are undocumented. This important extension of the Warren-Passel methodology to create an individual-level identifier for undocumented status relies on the same residual approach that was initially used to calculate the size of the undocumented population. 
Passel and Cohn (2014) provide a detailed description of the methodology they used to add an undocumented status identifier to the Annual Social and Economic Supplement (ASEC) files of the CPS. In rough terms, the methodology identifies the foreign-born persons in the sample who are likely to be legal, and then classifies the remainder as likely to be undocumented. In particular:

All immigrants entering the U.S. before 1980 are assumed to be legal immigrants. Then, the CPS data are corrected for known over-reporting of naturalized citizenship on the part of recently arrived immigrants... and all remaining naturalized citizens from countries other than Mexico and those in Central America are assigned as legal. Persons entering the U.S. as refugees are identified on the basis of country of birth and year of immigration...Then, individuals holding certain kinds of temporary visas (including students, diplomats and "hightech guest workers”) are...assigned a specific legal temporary migration status...Finally, some individuals are assigned as legal immigrants because they are in certain occupations (e.g., police officer, lawyer, military occupation, federal job) that require legal status or because they are receiving public benefits (e.g., welfare or food stamps) that are limited to legal immigrants. As result of these steps, the foreign-born population is divided between individuals with "definitely legal” status... and a group of "potentially unauthorized" migrants...[There is also] a check to ensure that the legal statuses of family members are consistent; for example, all family members entering the country at the same time are assumed to have the same legal status (Passel and Cohn, p. 23).

Passel and Cohn (2014) note that this approach tends to lead to "too many" undocumented immigrants. In other words, the residual number of persons predicted to be likely undocumented is larger than what would be expected from the DHS official counts. Passel and Cohn then apply a final filter to ensure that the counts from the microdata agree with the reported DHS numbers: "To have a result consistent with the residual estimate of legal and unauthorized immigrants, probabilistic methods are employed to assign legal or unauthorized status to these potentially unauthorized individuals.” The CPS sample is then reweighted so that the aggregate 
count of undocumented immigrants matches as closely as possible the DHS estimates, including the estimates of undocumented immigrants for the six largest states.

I was granted access to the 2012-2013 ASEC files that Passel constructed and that are maintained by the Pew Research Center. The top panel of Table 1 summarizes some summary statistics for natives, legal immigrants, and undocumented immigrants in the sample of persons aged 20-64. In the pooled 2012-2013 cross-sections, 5.4 percent of the population aged 20-64 was predicted to be composed of undocumented immigrants, and another 12.4 percent was composed of legal immigrants. The Pew imputation also suggest that undocumented immigrants are, on average, around 4 to 5 years younger than either natives or legal immigrants. The undocumented immigrants are also more likely to be male (54 percent as compared to around 49 percent for the other two nativity groups). And, finally, the undocumented are much more likely to be high school dropouts: 42 percent of the undocumented lack a high school diploma, as compared to only 19.2 percent of legal immigrants, and 7.1 percent of natives.

Figure 1 illustrates the percent of the U.S. population by age that is imputed to be undocumented in the Pew ASEC files. The DHS official counts imply that 3.7 percent of the U.S. population is undocumented. The Pew files suggest that a very high fraction (almost 10 percent) of persons in their early 30 s is undocumented.

Table 1 also reports the fraction of each group that worked during the CPS reference week - the key labor supply variable that will be used throughout the paper. There are interesting differences both across the three nativity groups and between men and women. In particular, undocumented men have by far the highest employment rates of any of the groups, while undocumented women have the lowest employment rates. The employment rate of undocumented men is 86.6 percent, as compared to 73.9 percent for natives and 77.8 percent for legal immigrants. In contrast, the employment rate of undocumented women is 54.6 percent, as compared to 66.9 percent for natives, and 58.7 percent for legal immigrants.

After being granted access to the Pew ASEC files (but not to the underlying code that creates the undocumented status identifier), I conducted a careful examination of the demographic characteristics of those persons identified as undocumented immigrants in the pooled 2012-2013 cross-sections. Despite the inherent complexity in the residual method of identifying the subsample of the likely undocumented, it turns out that only a relatively small number of variables really "matter" in the identification of undocumented persons. This fact 
suggests that it may be possible to reverse engineer the residual method to create a comparable undocumented identifier in all of the ASEC files since 1994 (the year in which immigration status began to be collected by the CPS).

The algorithm I use to create a comparable undocumented status identifier in all the relevant ASEC files is as follows. A foreign-born person will be classified as a legal immigrant if:

a. that person arrived before 1980;

b. that person is a citizen;

c. that person receives Social Security benefits, SSI, Medicaid, Medicare, or Military Insurance;

d. that person is a veteran, is currently in the Armed Forces;

e. that person works in the government sector;

f. that person resides in public housing or receives rental subsidies, or that person is a spouse of someone who resides in public housing or receives rental subsidies;

g. that person was born in Cuba (as practically all Cuban immigrants are granted refugee status);

h. that person's occupation requires some form of licensing (such as physicians, registered nurses, air traffic controllers, and lawyers;

i. that person's spouse is a legal immigrant or citizen.

The residual group of all other foreign-born persons is then classified as undocumented. Unlike the Pew methodology, my reconstruction of the undocumented identifier does not carry out any kind of probabilistic sampling to account for the "excess” number of undocumented immigrants that this residual method yields, nor does it reweigh the data in any fashion to ensure that the total counts of the undocumented match the DHS official counts. Throughout the analysis, the sample weights employed when I use the ASEC files that contain my reconstruction of the undocumented status identifier are the original CPS sampling weights.

As the bottom panel of Table 1 shows, there is a great deal of similarity between the summary statistics from the Pew files and from my reconstruction of the pooled 2012-2013 
ASEC cross-sections. ${ }^{4}$ Both methods yield a similar population of undocumented immigrants (5.4 percent in Pew and 5.7 percent in my reconstruction). Further, the percent male in the undocumented population is 54.3 percent in the Pew files and 55.9 percent in my reconstruction. The average age of undocumented immigrants is 37.6 years in both files. Similarly, 42.0 percent of the undocumented lack a high school diploma in the Pew cross-sections, while my reconstruction of the ASEC files predicts that this statistic is 39.5 percent. Similarly, as in the Pew files, the employment rate for undocumented men in the reconstructed files is far higher than that of native men or legal immigrant men, while the employment rate for undocumented women is far lower than that of native women or legal immigrant women.

It is also important to note that although my reconstruction does not conduct any probabilistic sampling of the data nor any type of reweighting, my approach yields a very similar geographic distribution for the location of the undocumented population: Around 23 percent of the undocumented live in California, 7.0 percent live in New York, and 15 percent live in Texas regardless of the method used. 5

Finally, as Figure 2 documents, the predicted fraction of undocumented immigrants in the population at any particular age is essentially the same regardless of whether I use the Pew files or the reconstructed files. The similarity between the two sets of data suggests that it is possible to extend the exercise to create an undocumented status identifier for all foreign-born persons sampled by the CPS throughout the entire 1994-2014 period. This extension allows for an examination of the differential long-term labor supply trends among natives, legal immigrants, and undocumented immigrants. ${ }^{6}$ It is important to reemphasize, however, that the validity of the statistical evidence will obviously depend on the accuracy of the process used to impute undocumented status. In the absence of administrative data on the characteristics of the

\footnotetext{
4 I experimented with a variety of sensitivity tests in the imputation of undocumented status. These alternative definitions include the "correction” of a reported naturalized citizenship status for any foreign-born person who has been in the country fewer than 5 years, or slightly different lists for the set of occupations that requires licensing. The results generated by the undocumented status identifier used in this paper are very representative of a wide array of alternative definitions.

5 Note that the number of observations for the pooled 2012-2013 ASEC cross-sections is larger in the Pew files because of the probabilistic sampling methods used to create the files. The actual number of observations in the CPS files (as released by the BLS) is the one given in Panel B.

6 I also obtained an alternative ASEC file from the Heritage Foundation for the 2011 cross-section that imputes an alternative undocumented status identifier. The Heritage methodology identifies a sample of undocumented persons that has very similar socioeconomic characteristics to the undocumented samples in the Pew files and in my reconstructed samples.
} 
undocumented population, it is not possible to quantify the direction and magnitude of any potential bias.

\section{Differences in Labor Supply across Groups}

I begin by documenting the differences in work propensities across the various nativity groups. The analysis initially uses the pooled 2012-2013 ASEC files created by Passel and colleagues at the Pew Research Center and is restricted to persons aged 20-64. Throughout the analysis, I will pool the two cross-sections and treat them as a single data set. The key measure of labor supply indicates if the person worked during the CPS reference week.

To document the differences in labor supply across the various groups-and to examine the source of these differences-I estimated the following regression model:

$$
p_{i}=\delta_{t}+\theta X_{i}+\beta_{1} L_{i}+\beta_{2} U_{i}+\varepsilon_{i}
$$

where $p_{i}$ is a dummy variable indicating if the person works during the reference week; $\delta_{t}$ is a dummy variable indicating if the observation is drawn from the 2012 or 2013 ASEC crosssection; $X_{i}$ is a vector of socioeconomic characteristics described below; $L_{i}$ is a dummy variable indicating if the person is a legal immigrant; $U_{i}$ is a dummy variable indicating if the person is an undocumented immigrant; and the excluded group indicates if person $i$ is native-born. The coefficients $\beta_{1}$ and $\beta_{2}$ measure the employment probability of the two foreign-born groups relative to that of natives. For simplicity, the regressions are estimated using the linear probability model, and are estimated separately for men and women.

The first two columns of Table 2 report the estimated regression coefficients in the vector $\beta$. The top panel of the table reports the coefficients estimated in the sample of men. As the first two rows indicate, it is evident that, on average, both legal and undocumented immigrants are more likely to be employed than native-born workers, and that this gap in work propensities remains when the regression adds a fourth-order polynomial in age. The age-adjusted difference in the work probability between legal immigrants and natives is around 2 percentage points, and that gap rises to 10 percentage points for undocumented immigrants. The finding that undocumented immigrant men are much more likely to be employed than either native or legal 
immigrant men is one of the key implications of the empirical analysis, and will be robust throughout the paper.

In fact, as the third row of the table shows, this gap becomes even larger after the regression controls for differences in educational attainment among the groups. As we saw from the summary statistics reported in the previous section, undocumented immigrants have far less education than either natives or legal immigrants. Once the regression controls for these differences in educational attainment by including a vector of education fixed effects, the employment gap between undocumented immigrants and natives widens from 10 to 17 percentage points, while the gap between legal immigrants and natives only widens by around 1 percentage point. ${ }^{7}$ Finally, as row 4 of the table shows, these employment gaps remain stable when the regression model is expanded further to include a vector of state of residence fixed effects and an indicator of whether the person lives in a metropolitan area to account for the different geographic settlement of the three groups.

The last two columns of Table 2 re-estimate the regression in equation (1) using the comparable ASEC files (i.e., for the 2012-2013 cross-sections) that contain my reconstructed undocumented status indicator. It is evident that the employment gaps across the three groups are roughly similar to those obtained from the Pew files. For example, the employment gap between undocumented immigrants and natives in the most general specification (in row 4) is 17 percentage points in the Pew files and 14.0 percentage points in my reconstruction.

The bottom panel of the table estimates the regressions using the sample of women in both the PEW files and the reconstructed CPS files. As was first suggested by the summary statistics, the regressions (regardless of which CPS files is used) indicate that immigrant women work less than native women, and that undocumented women are the group that is least likely to be employed. Interestingly, the results for immigrant women are essentially a reverse image of the results for immigrant men.

Specifically, the age-adjusted probability that a legal immigrant woman works is around 9 percentage points lower than that of a native women, and that gap widens to 14 percent points for undocumented women. Moreover, as row 3 of the table indicates, these gaps narrow (rather than widen as in the case of men) after we control for differences in educational attainment

\footnotetext{
7 The vector of fixed effects indicating educational attainment indicate if the person is a high school dropout, a high school graduate, has some college, or is a college graduate.
} 
among the groups. Both legal and undocumented immigrant women have work propensities that are around 4 to 6 percentage points lower than those of comparably skilled native women.

It is useful to continue the descriptive analysis by examining the work propensity gaps at various points in the life cycle. I smooth out the age-employment profiles by estimating the following logit regression in the pooled 2012-2013 ASEC cross-sections: ${ }^{8}$

$$
\log \frac{p_{i}}{1-p_{i}}=\beta_{1} L_{i}+\beta_{2} U_{i}+\theta_{0} \mathbf{A}_{i}+\theta_{1}\left(L_{i} \times \mathbf{A}_{i}\right)+\theta_{2}\left(U_{i} \times \mathbf{A}_{i}\right)+\delta_{t}+\varepsilon_{i}
$$

where $\mathbf{A}_{\mathrm{i}}$ is a vector of variables containing a fourth-order polynomial in person $i$ 's age. The interactions between the immigration status indicators and the age vector, of course, allow for the age-employment profiles to vary across the three groups. The logit regressions are estimated separately for men and women. The predicted age-employment profiles from the logistic regression very closely track the raw data for all the nativity groups.

The two panels of Figure 3 illustrate the predicted age-employment profile for men and women implied by the logit regressions in equation (2). It is evident that the employment gap between undocumented and native men is present over the entire life cycle. It is of interest to note that the employment gap is quite large (around 20 percentage points) when the two groups near retirement age, and narrower (around 7 percentage points) in the middle of the life cycle when the men are in their 40s. In contrast, undocumented women are far less likely to work than both natives and legal immigrant women throughout much of the life cycle, and that gap is around 15 to 20 percentage points when the women are in their 30s and 40s.

It is instructive to document the similarity in the predicted age-employment profiles when the logistic model in equation (2) is estimated using my reconstruction of the undocumented status indicator. Figure 4 shows the comparable age-employment profiles for natives, legal immigrants, and undocumented immigrants. It is evident that the reconstruction of the undocumented status identifier leads to age-employment profiles that are very similar in the two data sets (although the employment gap between undocumented men and natives is somewhat

\footnotetext{
8 I use a logistic regression, rather than a linear probability model, so that the predicted work probability lies between 0 and 1 .
} 
smaller in my reconstruction). This similarity suggests that the reconstructed CPS files can be used to examine the labor supply trends of the various groups over a longer span of time.

Finally, as implied by the regression analysis in Table 2, it is the case that adjusting for education widens the employment gap between undocumented and native men and narrows the equivalent gap for women. Specifically, I re-estimated the logit regression in equation (2) by adding a vector of education fixed effects. Figure 5 illustrates the predicted education-adjusted age-employment files for both men and women in the Pew ASEC files (where the work probability is calculated at the mean educational attainment of undocumented workers). In the case of men, the employment gap between undocumented and native men is now much larger at every age and nears 30 percentage points for older men. In contrast, adjusting for differences in educational attainment narrows the employment gap between undocumented and native women over much of the life cycle.

\section{Trends in the Labor Supply of Undocumented Immigrants}

It is well known that there has been a steep and long-term decline in the labor supply of men over the past few decades, and that this decline perhaps accelerated after the onset of the Great Recession in 2008 (Aaronson et al., 2006; Aaronson et al., 2014; Farber, 2011). This section documents the differences in the secular trends among the three nativity groups using the reconstruction of the undocumented indicator status in the ASEC files between 1994 and 2014.

Panel A of Figure 6 illustrates the long-term trends in the employment probability of men over the two decades. The figure reveals a number of interesting facts. First, there are the obvious cyclical ups and downs in employment that affect all three groups. Second, and more important, although the employment rate of the three groups was roughly similar in the mid1990s (hovering around 80 percent), there has been a marked divergence in employment among the groups in the past decade. By 2014, the employment rate of undocumented immigrants was far larger than that of legal immigrants, which in turn was far larger than that of native men. Specifically, the employment rate of undocumented immigrants had risen to 85 percent, that of legal immigrants stood at 81 percent, and that of natives had fallen to 74 percent.

It is easy to visualize the divergence among the three groups by netting out the yearspecific cyclical factors from the trend of each group. In particular, the bottom panel of Figure 6 redraws the trends after subtracting from each of the trend lines the average employment rate of 
the population aged 20-64 in each year. It is evident that there has been a long-term decline in the employment rate of native men—amounting to around 2 percentage points between 1996 and 2014. Similarly, there has been a steady increase in the employment rate of legal immigrant men, amounting to around 6 percentage points over the period. Finally, there has been a steeper increase in the employment rate of undocumented men, amounting to around 10 percentage points between the mid-1990s and 2014. ${ }^{9}$ Note also that the cyclically adjusted trend line for each of the employment rates for each group can be reasonably approximated by a linear trend. This fact provides a simple way for determining which factors may be responsible for these differential long-term trends in employment propensities.

There is one final insight provided by the two panels of Figure 6 that is worth emphasizing.. The relative rise in the employment rate of immigrants over the past two decades, both for legal and undocumented immigrants, cannot be attributed solely to the fact that the employment rates of natives declined. In addition to this decline in native employment propensities, there was also an independent and rapid rise in the employment rate of immigrant men.

The two panels of Figure 7 present the analogous long-term employment trends for women. As suggested by the descriptive evidence in the pooled 2012-2013 cross-sections documented in the previous section, there are many differences in the trends between men and women. First, the cyclically-adjusted employment rate of native women shown in Panel Bunlike that of native men - did not decline over the past two decades, but was instead very steady. Second, the employment rates of immigrant women—both undocumented and legal—are not higher than those of natives, but are instead lower. Finally, the long-term (and cyclicallyadjusted) increase in the employment rate for women was strongest among legal immigrants, rather than among undocumented immigrants.

The employment trends illustrated in Figures 6 and 7 raise an important question: Which factors account for the differential trends among natives, legal immigrants, and undocumented immigrants? Even apart from the cyclical fluctuations, the 1994-2014 period witnessed many

\footnotetext{
${ }^{9}$ It is important to emphasize that these descriptive differential trends should not be interpreted as providing evidence of a causal relationship between the increase in the employment rate of undocumented men and the decline in the employment rate of native men.
} 
other important economic shocks, including the well-documented changes in the wage structure that have been studied extensively in the literature (Lemieux, 2006).

To isolate the potential factors that may be responsible for the differential employment rends, I use a generalized regression specification that allows me to account for changes in the returns to skills and for potential differences in the cyclical effects among skill groups. Specifically, I classify workers into skill groups defined by education and age. I categorize workers into one of four education groups: persons who are high school dropouts (i.e., they have less than 12 years of completed schooling), high school graduates (they have exactly 12 years of schooling), persons who have some college (they have between 13 and 15 years of schooling), and college graduates (they have at least 16 years of schooling). Further, I classify workers into age groups that are composed of 5-year bands: 20-24, 25-29, 30-34, etc. There are, therefore, a total of 36 skill groups in the analysis (i.e., 4 education groups and 9 experience groups).

I stack all the 1994-2014 ASEC cross-sections that contain my reconstruction of the undocumented status identifier and estimate the following regression model in the stacked data:

$$
p_{i t}=\delta_{t}+\theta X_{i}+\beta_{1} L_{i}+\beta_{2} U_{i}+\gamma_{1}\left(L_{i} \times T\right)+\gamma_{2}\left(U_{i} \times T\right)+\varepsilon_{\mathrm{it}},
$$

where $\delta_{t}$ represents a vector of fixed effects indicating the year of the ASEC cross-section; $T$ is a linear trend (set equal to 1 in 1994); and $L_{i}$ and $U_{i}$ are the dummy variables indicating whether person $i$ is a legal or an undocumented immigrant, respectively. The interactions between the linear trend $T$ and the legal and undocumented status indicator variables, of course, essentially estimate the differential slopes in the cyclically adjusted labor supply trends (relative to natives) documented in the bottom panels of Figures 6 and 7. The regression is estimated using alternative sets of variables in the vector $X$ to determine the extent to which these background characteristics can "explain” the differential slopes in the employment trends. The regressions are estimated separately in the samples of men and women.

The first column in Panel A of Table 3 estimates the basic regression where there are no controlling socioeconomic characteristics in the vector $X$, and the coefficients in the vector $\gamma$ are essentially imposing a linear path on the cyclically adjusted differential trend between each type of immigrant and natives. Consider initially the results in the male sample. The coefficient for legal immigrants is .002, implying that over a 20-year period (the span of the data), the 
employment rate of legal immigrants increased by about 4 percentage points relative to that of natives. Similarly, the coefficient for undocumented immigrants is .007 , so that over the 20 -year span the relative employment rate of undocumented immigrants increased by nearly 14 percentage points.

The remaining columns of the table re-estimate the regression by adding variables to the vector $X$ to determine the sensitivity of the interaction coefficients $\gamma_{1}$ and $\gamma_{2}$ to the inclusion of these socioeconomic characteristics. Column 2, for example, includes a vector of fixed effects indicating the person's skill group (i.e., the person's particular combination of education and age). Note that controlling for skills in this general fashion seems to explain part of the differential trends. Specifically, adjusting for skills cuts in half the slope of the relative trend line for undocumented immigrant men, from .0074 to .0035 . After adjusting for skills, the relative employment of undocumented immigrants increased by around 7 percentage points over the 20year period — which is still a very sizable increase (though far smaller than the 14 percentage point increased predicted by the unadjusted regression coefficient in column 1).

It is possible, however, that the inclusion of the skill fixed effects in this fashion (simply as a set of dummy variables indicating which skill group person $i$ belongs to) does not fully capture the dramatic changes that occurred in the wage structure during the period. These changes in the wage structure likely affected the wages of the 36 skill groups in the analysis in very different ways, and it may be that these disparate changes in wages may be responsible for the differential trends in labor supply among the three nativity groups.

To account for these structural changes in the wage distribution in a generalized fashion, the third column of the table re-estimates the regression by including a vector of fixed effects that interacts the 36 skill fixed effects with the 21 year fixed effects, thus allowing differential period effects for each of the skill groups. It is worth emphasizing that the inclusion of these skill-year interactions controls for any period- and skill-specific "shocks" that would eventually affect labor supply.

Despite the very general way in which the changes in the wage structure (as well as any other skill-year shocks that independently affect labor supply) are incorporated into the regression, note that the interaction coefficients $\gamma_{1}$ and $\gamma_{2}$ actually rise slightly to .002 and .005 in column 3 of Table 3. In short, even after controlling for the impact of the changing wage structure on the economic opportunities of narrowly defined skill groups, the relative 
employment rate of legal immigrant men is still predicted to increase by around 4 percentage points over a 20-year period, and that of undocumented men by around 10 percentage points over the period.

Finally, although the regression controls for aggregate cyclical effects, and for skillspecific cyclical effects, it may be possible that because the three groups settle in distinct geographic areas, the cyclical effects that affect each of the groups is different due to this differential geographic clustering. The geographic clustering might matter because of geographic differences in industrial structure, the occupational composition of jobs, and the economic policies pursued by different localities that might affect the three groups differentially.

The specification of the regression model in equation (3) allows me to again determine the extent to which these geographic-cyclical interactions affect the differential trends in employment in a general way. Specifically, the last column of Table 3 adds a vector that interacts the year fixed effects with a vector of state of residence fixed effects, thus allowing for the possibility that there are state-year specific shocks that affect the labor supply of the three nativity groups differentially.

The regression coefficients reported in the last column of Table 3 make it evident that the relevant coefficients $\gamma_{1}$ and $\gamma_{2}$ are barely affected by the adjustment for state-year specific shocks. In short, even after controlling for differential trends in returns to skills across skill groups and for differential impacts of the business cycle across geographic regions, a simple fact remains: the relative employment rate of legal immigrants increased by about 3.6 percentage points over the 1994-2014 period, while the relative employment rate of undocumented immigrants increased by 9.4 percentage points.

Remarkably, the key lesson resulting from this exercise is that the "usual suspects" do not explain why the three nativity groups experienced such differential trends in labor supply over the 1994-2014 period. There is evidence that part of the difference in the long-term trends can be accounted for by the skill differences among the three nativity groups. However, even after the regression exhaustively controls for these skill differences—and adjusts for the possibility that economic conditions varied dramatically over time for each of the narrowly defined skill groups, as well as for the possibility that economic conditions varied dramatically among the different geographic regions where the three groups tend to settle-it is still the case that the employment 
rate of immigrants, and particularly that of undocumented immigrant men, increased dramatically relative to that of native-born persons.

The fact that the usual list of economic variables do not seem to explain much of the differential trends in labor supply across the three nativity groups is consistent with other recent research that attempts to explain the decline in the labor supply observed among (all) workers during the past few years. For instance, a recent study by Barnichon and Figura (2015), for example, notes that some of the employment decline cannot be traced back to changing economic conditions per se, but rather to changes in the "desire" to work by persons outside the labor force. ${ }^{10}$ It is unclear, however, which factors are driving these changing preferences towards work. The regression analysis summarized in Table 3 suggests that these factors, whatever they may be, are not correlated with specific skill or geographic trends. As a result, the factor driving the relative increase in employment of legal and undocumented immigrants remains unexplained as well. 11

Finally, the bottom panel of Table 3 re-estimates the regression model in the stacked sample of women. As with men, the key finding is that the inclusion of the various variables that attempt to control for changes in skill prices or in cyclical conditions cannot explain why the relative employment of immigrant women increased relative to that of native women over the 20-year period. In the most general regression presented in the last column of the table, which allows for differential period affects across skill groups and across geographic areas, it is evident that the relative employment rate of undocumented women increased by a net 2.4 percentage points over the 20-year period, while that of legal immigrant women increased by around 3 percentage points.

10 See also Fujita (2014) and Hotchkiss and Rios-Avila (2013). The low explanatory power of the usual economic variables in determining the decline in labor force participation is also noted by Fujita who writes: "Almost all of the decline (80 percent) in the participation rate since the first quarter of 2012 is accounted for by the increase in nonparticipation due to retirement... The likelihood of those who left the labor force due to retirement or disability rejoining the labor force is small and has been largely insensitive to business cycle conditions in the past, suggesting that the decision to leave the labor force for those two reasons is more or less permanent” (Fujita, 2014, p. 1).

11 One possible hypothesis is that the employment rate of undocumented workers remained high because the flow of undocumented immigrants slowed down or reversed due to poor economic conditions, making the supply of undocumented workers relatively more scarce in recent years; see Nakamura (2013). 


\section{Estimates of the Labor Supply Elasticity}

The previous section documented that the usual list of socioeconomic characteristics does not provide an adequate explanation of why the labor supply of immigrant men-and particularly that of undocumented men-rose over the past two decades both in absolute and relative terms. This section of the paper explores a related question by examining the extent to which the labor supply of the three nativity groups is linked to systematic changes in the wage. It turns out that the labor supply of immigrants_-and again particularly the labor supply of undocumented immigrants-is far less responsive to wage changes than the labor supply of natives. In fact, the data clearly indicate that it seems reasonable to infer that the labor supply of undocumented men is perfectly inelastic.

For obvious reasons, it is not possible to easily estimate the responsiveness of the employment propensity to wage changes simply because the wage is not observed for nonworkers. Although it is potentially feasible to estimate selectivity-corrected wage estimates for the sample of non-workers, and then use a more sophisticated model to estimate various measures of labor supply responsiveness to wage changes, I opt for a simpler (and probably more empirically robust) method. In particular, I aggregate the data into age-education-nativity groups in each of the ASEC cross-sections, and estimate various types of labor supply functions using this aggregate data.

Specifically, I classify persons into the 36 skill groups defined in the previous section. The four education groups indicate if a person is: a high school dropouts; a high school graduate; has some college; or is a college graduate. Similarly, the nine age groups specify if a person is: 20-24 years old, 25-29 years old, and so on. Within each of these skill groups, there are three types of persons: the native-born, the legal immigrants, and the undocumented immigrants.

For each of these age-education-nativity cells, I then calculated (separately by gender) three alternative measures of labor supply at time $t$ : the fraction of the group that is employed in the CPS reference week; the average log hours worked annually in the sample of workers; and the log of the average hours worked annually across all persons in the age-education-nativity group, including the sample of non-workers.

For each skill group, I also estimated the "market wage” facing the particular ageeducation group at a point in time. This market wage is given by the average of the hourly wage 
rate of workers in the age-education group in each ASEC cross-section. ${ }^{12}$ I calculated the average log wage for the skill group at time $t$ separately in the sample of men and women.

By stacking the aggregated data for the 108 age-education-nativity groups across all CPS cross-sections between 1994 and 2014, it is then possible to estimate the regression model:

$$
\begin{aligned}
h_{a s n t}= & \phi_{a}+\phi_{s}+\phi_{n}+\phi_{t}+\phi_{a t}+\phi_{s t}+\phi_{n t}+\phi_{a s n} \\
& +\sigma_{N}\left(\log w_{a s t} \times N\right)+\sigma_{L}\left(\log w_{a s t} \times L\right)+\sigma_{U}\left(\log w_{a s t} \times U\right)+\varepsilon_{a s n t}
\end{aligned}
$$

where $h_{a s n t}$ is the averaged measure of labor supply for cell $(a, s, n, t)$, and $\log w_{a s t}$ is the mean log wage of workers in the particular age-education group at time $t$. Note that the log wage is interacted with indicators of whether the cell represents persons who are native born $(N)$, or legal immigrants $(L)$, or undocumented immigrants $(U)$, so that the regression allows the labor supply elasticity to vary across the three nativity groups.

The vectors $\phi_{a}, \phi_{s}, \phi_{n}$, and $\phi_{t}$ represent fixed effects indicating the group's age, education, nativity status, or the year in which the cross-section is observed. The interactions $\phi_{a t}$, $\phi_{n t}$, and $\phi_{s t}$ allow for the impact of the age, education, and nativity fixed effects to vary over time. Finally, the inclusion of the age-education-nativity interactions $\phi_{a s n}$ implies that the impact of the wage on labor supply is being identified from changes that occur within an age-education-nativity group, and this wage response is allowed to vary among the three nativity groups.

The top panel of Table 4 reports the estimates of the regression coefficients in the vector $\sigma$ estimated in the sample of men. It is evident that the correlation between labor supply and wages within an age-education-nativity group is much stronger for natives than it is for legal immigrant, which in turn is much stronger than it is for undocumented immigrants.

Consider, for example, the coefficients reported in column 1, where the dependent variable is the fraction of the group that is employed in the CPS reference week. The elasticity $\sigma_{N}$ is .234 (with a standard error of .015). This elasticity is about half the size for legal

12 Because the sample size of some of the age-education-nativity groups is very small, the market wage is calculated at the age-education group level, rather than at the age-education-nativity group level. This aggregation helps to minimize the measurement error in the key independent variable in the regression model estimated below. 
immigrants, or .094 (.025). And the elasticity nears zero and is statistically insignificant for undocumented men, or .042 (.041).

The coefficients reported in column 2 of the table are obtained from a regression where the dependent variable is the log annual hours worked for the age-education-nativity group calculated in the sample of workers. The regression coefficients in this context, of course, attempts to estimate the labor supply elasticities implied by an interior solution to the neoclassical labor-leisure model. These labor supply elasticities are again positive for natives, but negative (and insignificantly different from zero) for both legal and undocumented immigrants. 13

Finally, the third column of the table reports the regression coefficients when the dependent variable is the log of the average number of hours worked across all persons in the ( $a$, $s, n, t)$ cell, including non-workers. In this case, the elasticity of labor supply for natives is again positive and significant (the coefficient is .355, with a standard error of .038). It is less positive, but still significant, for legal immigrants (the coefficient is .102 with a standard error of .037). And it is numerically and statistically equal to zero for undocumented immigrants.

In short, a common finding in Panel A of the table is that the labor supply of undocumented immigrants is far less responsive to systematic changes in the price of skills than that of either legal immigrants, and far less responsive that that of native-born persons. As noted earlier, it seems that the labor supply of undocumented immigrant men is very inelastic. This finding is consistent with a frequent conjecture that is made about undocumented immigrationthat "undocumented immigrant men come to the United States to work." It is clear that the data strongly support this conjecture. Undocumented immigrant men, as identified by the residual method of imputation pioneered by Pew, work regardless of the surrounding economic conditions.

To present an even more convincing case for the near-zero labor supply elasticities that seem to characterize the population of undocumented men, it is helpful to visually illustrate the evidence. Figure 8 presents the raw data—without any type of statistical adjustment—relating

13 The labor supply elasticities estimated when the dependent variable is hours worked would be qualitatively similar if the regression were estimated using individual-level data rather than the age-educationnativity aggregate cells used by the model in equation (4). The labor supply elasticities resulting from an individuallevel regression that uses a worker's actual wage (rather than the aggregated wage of workers in the skill cell) as the key independent variable are .020 (.005) for native men, -.005 (.009) for legal immigrant men, and -.046 (.015) for undocumented men. 
the group average of log hours worked (including non-workers) to the group average wage in the sample of men across cells $(a, s, n, t)$. It is obvious that the "labor supply curve" is quite steep and positively sloped for native men; that the curve is positively sloped, but not quite as steep, for legal immigrant men; and that the curve is essentially flat for undocumented men.

The fact that labor supply is inelastic for undocumented men has important implications for any future analysis that attempts to predict the consequences of legislation or executive orders that regularize the status of undocumented immigrants. As an example, such regularization is likely to be accompanied by an increase in the average wage of undocumented immigrant men. This wage increase is not surprising because the newly legalized status opens up many additional employment opportunities for the previously undocumented workers. A number of studies have examined what happened to the earnings of persons who received amnesty in 1986 as part of the Immigration Reform and Control Act (IRCA). Nearly 3 million illegal immigrants received amnesty at the time, and contemporaneous surveys tracked those immigrants as they received their legal working papers. Their wage rose by around 6 percent between 1989 and 1992 (Kossoudji and Cobb-Clark, 2002; and Kaushal, 2006).

The wage increase resulting from any regularization of immigration status would, of course, generate both income and substitution effects on labor supply. If the labor supply elasticities estimated in Table 3 were to remain constant after the regularization takes place, the evidence clearly suggests that we should not expect much of a change in the labor supply of undocumented immigrant men.

We do not know, of course, the extent to which the elasticity $\sigma_{U}$ is affected by undocumented status per se. Nevertheless, the fact that legal immigrant men have labor supply elasticities which are themselves much smaller than those of native men-despite any legal restrictions on the type of employment that they can have-suggests that a change in the status of undocumented immigrant men will not lead to a substantial change in labor supply.

The bottom panel of the table re-estimates the regression models in the sample of women. The labor supply elasticities for native women are very similar as those estimated for native men. In column 1, for example, the labor supply elasticity is .234 (.015) for men and .315 (.015) for women. This finding is consistent with recent evidence showing a dramatic convergence in the magnitude of the labor supply elasticities for men and women (Blau and Kahn, 2007). Given the nature of the evidence for female labor supply reported in earlier sections of this paper, however, 
it is not surprising that the gender similarity in labor supply elasticities does not hold for immigrants. Immigrant women—both legal and undocumented-have much higher labor supply elasticities than immigrant men, although these elasticities are still somewhat lower than they are for native women. As a result, any wage increase resulting form the potential regularization of status for undocumented immigrant women is likely to increase their labor supply.

It is possible that the total lack of responsiveness of labor supply to wages in the sample of undocumented immigrant men could arise because the various nativity groups were differentially affected by the cyclical fluctuations in the past two decades. Although the overall impact of the business cycle is netted out through the period effects (as well as the interaction of these period fixed effects with education, experience, and nativity group fixed effects), it may well be that the different groups are affected differentially by cyclical fluctuations because the three groups tend to settle in different geographic regions. It is easy to expand the regression model in equation (4) to account for region-specific differences in economic conditions.

Specifically, I conduct an alternative aggregation of the data by classifying persons into region-age-education-nativity cells. The generic regression model then becomes:

$$
\begin{aligned}
h_{\text {rasnt }}= & \phi_{r}+\phi_{a}+\phi_{s}+\phi_{n}+\phi_{t}+\phi_{r t}+\phi_{a t}+\phi_{s t}+\phi_{n t}+\phi_{a s n} \\
& +\sigma_{N}\left(\log w_{a s t} \times N\right)+\sigma_{L}\left(\log w_{a s t} \times L\right)+\sigma_{U}\left(\log w_{a s t} \times U\right)+\varepsilon_{a s n t},
\end{aligned}
$$

where $r$ indicates the state of residence of person $i$; the vector $\phi_{r}$ represents a vector of state fixed effects; and the interaction $\phi_{r t}$ allows these state effects to vary over time.

The last column of Table 4 report the labor supply elasticities resulting from these alternative regressions using the measure of labor supply that gives the log of the average annual hours worked (including non-workers). It is clear that the magnitude of the estimated coefficients in the vector $\sigma$ are not dramatically altered by controlling for the possibility that the different geographic settlement of the different groups led to systematic changes in economic opportunities that affected their behavioral response to the wage change. ${ }^{14}$ In other words, the

\footnotetext{
14 Due to sample size constraints I do not attempt to estimate the average wage of each group in each stateskill-year cell, so that the average wage is still estimated at the skill-year cell level. This approach helps to minimize the contamination due to measurement error in the independent variable.
} 
labor supply of native men continues to be most responsive to wage changes, while the labor supply of undocumented men continues to be unresponsive.

Finally, it is important to emphasize that the estimates of the labor supply elasticities rely on my reconstruction of the undocumented status indicator applied to all ASEC files between 1994 and 2014. It is easy to show that the finding of inelastic labor supply for undocumented workers is not an artifact of my reconstruction of the undocumented status variable The evidence on labor supply elasticities is very similar if the regressions were re-estimated on the 2012-2013 pooled cross-section using the Pew Research Center ASEC files. ${ }^{15}$

As Table 5 shows, the labor supply elasticities estimated in the pooled 2012-2013 CPS using either the Pew files or my reconstruction of the undocumented status indicator in those files are essentially the same numerically. More importantly, both sets of estimates document the dramatic unresponsiveness of labor supply to systematic wage changes among undocumented men. In the Pew files, for example, the third column (where the dependent variable is the log of average hours worked, including nonworkers) the labor supply elasticity is .395 (.055) for natives and .046 (.051) for undocumented immigrants. In the ASEC cross-sections that use my reconstruction of the undocumented status indicator, the labor supply elasticity is .419 (.069) for natives and .038 (.058) for undocumented immigrants. In short, to the extent that the residual imputation method used by Pew to impute undocumented status at the micro level is reasonably accurate, the evidence is unambiguous: The labor supply of undocumented men is quite inelastic.

\section{Summary}

The last decade has witnessed a series of Congressional attempts to enact comprehensive immigration reform. A central component of such reform involves the creation of some type of "path to citizenship" for the 11.4 million undocumented immigrants residing in the United States. President Obama has also issued executive orders (now pending in the judicial system) that grant some form of amnesty to about half of this population..

This paper uses newly developed extensions of the Current Population Surveys that attempt to identify undocumented status for each person in the sample. The existence of such an

15 As I did in earlier sections, I treat these two files as a single cross-section because it would be difficult to allow for the vast number of interaction effects in the small samples that would result if the data were treated as a panel. Moreover, economic conditions did not vary all that much between 2012 and 2013. 
undocumented identifier at the individual level allows a full examination of the differences in various economic outcomes that distinguish the undocumented population from the population of legal immigrants, as well as from the native-born.

In particular, the paper examines the labor supply behavior of undocumented immigrants, both at a point in time as well as the trends over the 1994-2014 period, a period marked both by rapid economic growth as well as a deep recession. The analysis yields a number of new insights into the labor supply behavior of this sizable population:

1. Undocumented immigrant men are far more likely to work than other groups, while undocumented immigrant women are far less likely to work.

2. The employment gap that distinguishes undocumented men from the other groups widened dramatically over the past twenty years. By 2014, the probability that an undocumented man was employed in the CPS reference week was around 12 percentage points larger than that of native men. The probability that undocumented women are employed also grew at a relatively faster rate, but the increase was far less dramatic.

3. The labor supply of undocumented workers is not as responsive to wage changes as the labor supply of the other groups in the population. In fact, the data clearly suggest that the labor supply of undocumented men is almost perfectly inelastic.

It is important to emphasize that the analysis reported in this paper represents but a first step in any evaluation of the various regularization proposals that are being discussed in the policy arena. Much more needs to be discovered and documented about the economic status and well being of the undocumented population before a full assessment can be conducted. Similarly, it is important to further assess the accuracy of the imputation method used to identify a person's undocumented status at the micro level. The empirical analysis reported in this paper, however, illustrates the promise and importance of the availability of microdata files that contain an undocumented identifier. 


\section{References}

Aaronson, Stephanie, Bruce Fallick, Andrew Figura, Jonathan Pingle, and William L. Wascher. 2006. "The Recent Decline in Labor Force Participation and its Implications for Potential Labor Supply.” Brookings Papers on Economic Activity (1): 69-154.

Aaronson, Stephanie, Tomaz Cajner, Bruce Fallick, Felix Galbis-Reig, Christopher L. Smith, and William Wascher. 2014. "Labor Force Participation: Recent Developments and Future Prospects,” Brookings Papers on Economic Activity (1): 197-275.

Baker, Bryan, and Nancy Rytina. 2013. "Estimates of the Unauthorized Immigrant Population Residing in the United States: January 2012,” Washington, DC Department of Homeland Security, Office of Immigration Statistics.

Barnichon, Regis and Andrew Figura. 2015. "Declining Desire to Work and Downward Trends in Unemployment and Participation,” in Martin Eichenbaum and Jonathan Parker, editors, NBER Macroeconomics Annual 2015 (30): forthcoming.

Francine D. Blau and Lawrence M. Kahn. 2007. "Changes in the Labor Supply Behavior of Married Women: 1980-2000." Journal of Labor Economics 25(3): 393-438.

Bohn, Sarah and Magnus Lofstrom. 2012. "Employment Effects of State Legislation against the Hiring of Unauthorized Immigrant Workers.” San Francisco, CA: Public Policy Institute of California, December.

Bohn, Sarah, Magnus Lofstrom, and Steven Raphael. 2014. "Did the 2007 legal Arizona Workers Act Reduce the State's Unauthorized Immigrant Population.” Review of Economics and Statistics 96(2): 258-269.

Farber, Henry S. “Job Loss in the Great Recession: Historial Perspective from the Displaced Workers Survey, 1984-2010.” NBER Working Paper No. 17040, May 2011.

Fujita, Shigeru. 2014. “On the Causes of Declines in the Labor Force Participation Rate.” Philadelphia, PA: Federal Reserve Bank of Philadelphia, Research Rap.

Goss, Stephen, Alice Wade, J. Patrick Skirvin, Michael Morris, K. Mark Bye, and Danielle Huston, "Effects of Unauthorized Immigration on the Actuarial Status of the Social Security Trust Funds,” Actuarial Note Number 151, Social Security Administration, Office of the Chief Actuary, Washington, DC, April 2013.

Hotchkiss, Julie L., and Fernando Rios-Avila. 2013. "Identifying Factors Behind the Decline in the U.S. Labor Force Participation Rate.” Business and Economic Research, Macrothink Institute 3 (1): 257-275. 
Kossoudji, Sherrie A. and Deborah A. Cobb-Clark. 2002. "Coming out of the Shadows: Learning about Legal Status and Wages from the Legalized Population.” Journal of Labor Economics 20(3): 598-628.

Kaushal, Neeraj. 2006. “Amnesty Programs and the Labor Market Outcomes of Undocumented Workers.” Journal of Human Resources 16(3): 631-647.

Lemieux, Thomas. 2006. "Increasing Residual Wage Inequality: Composition Effects, Noisy Data, or Rising Demand for Skill?" American Economic Review 96(3): 461-498.

Nakamura, David. 2013. "Number of illegal immigrants in U.S. dropped during recession, study finds,” Washington Post, September 23.

Passel, Jeffrey S. and D’Vera Cohn. 2014. “Unauthorized Immigrant Totals Rise in 7 States, Fall in 14 States: Decline in Those From Mexico Fuels Most State Decreases.” Washington, DC: Pew Research Center.

Warren, Robert E. and Jeffrey S. Passel. 1987. "A Count of the Uncountable: Estimates of Undocumented Aliens Counted in the 1980 United States Census.” Demography 24(3): 375-393. 
Figure 1. Percent foreign-born in population, by age (Pooled CPS-ASEC files created by Pew Research Center, 2012-2013)

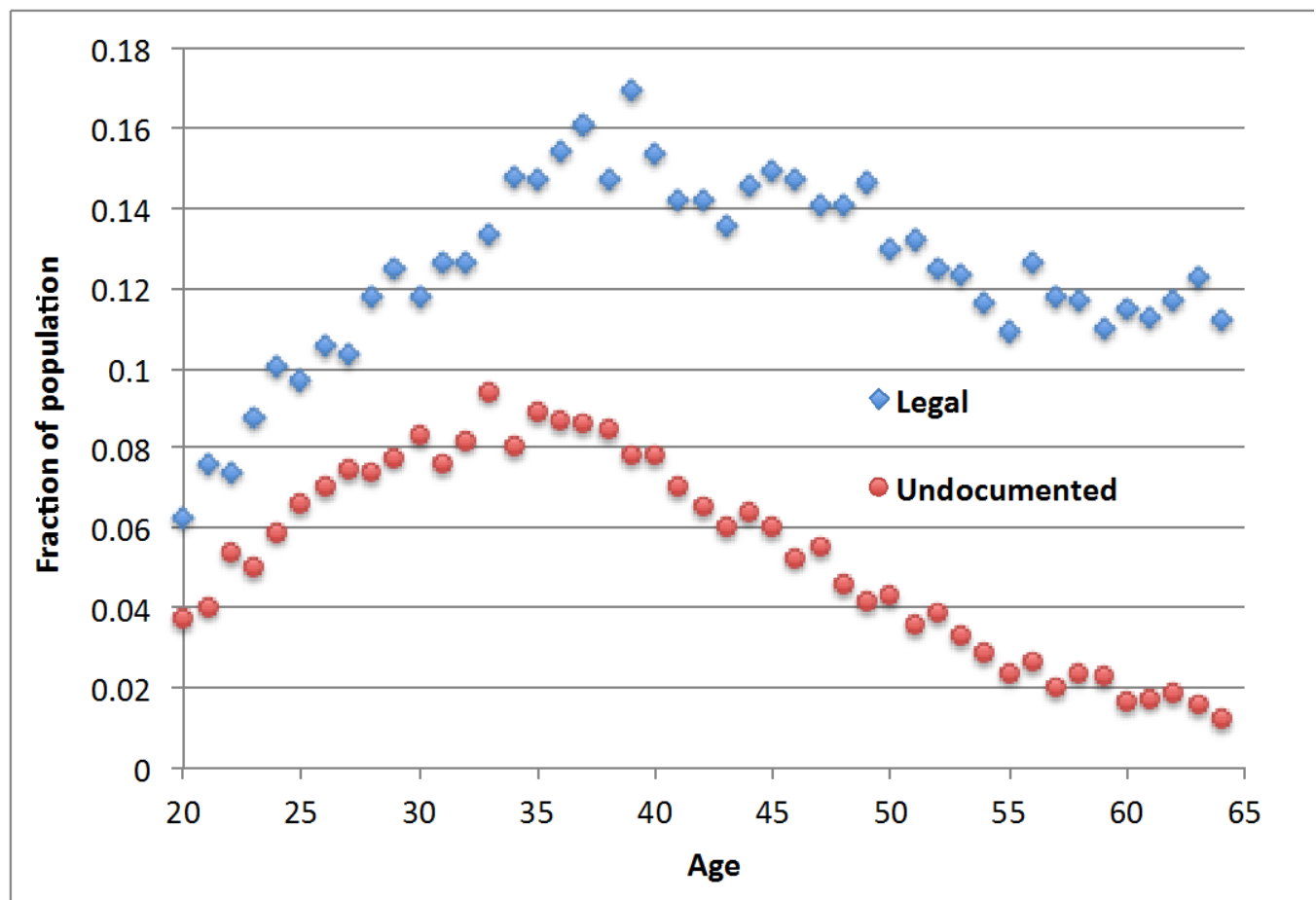

Notes: The figure calculates the percent of the population (at a particular age) that is foreign-born and is classified as either "likely authorized" or "likely unauthorized" using the undocumented status indicator created by Jeffrey Passel and colleagues at the Pew Research Center. 
Figure 2. Percent of population that is undocumented, by age (Pooled 2012-2013 CPS-ASEC files)

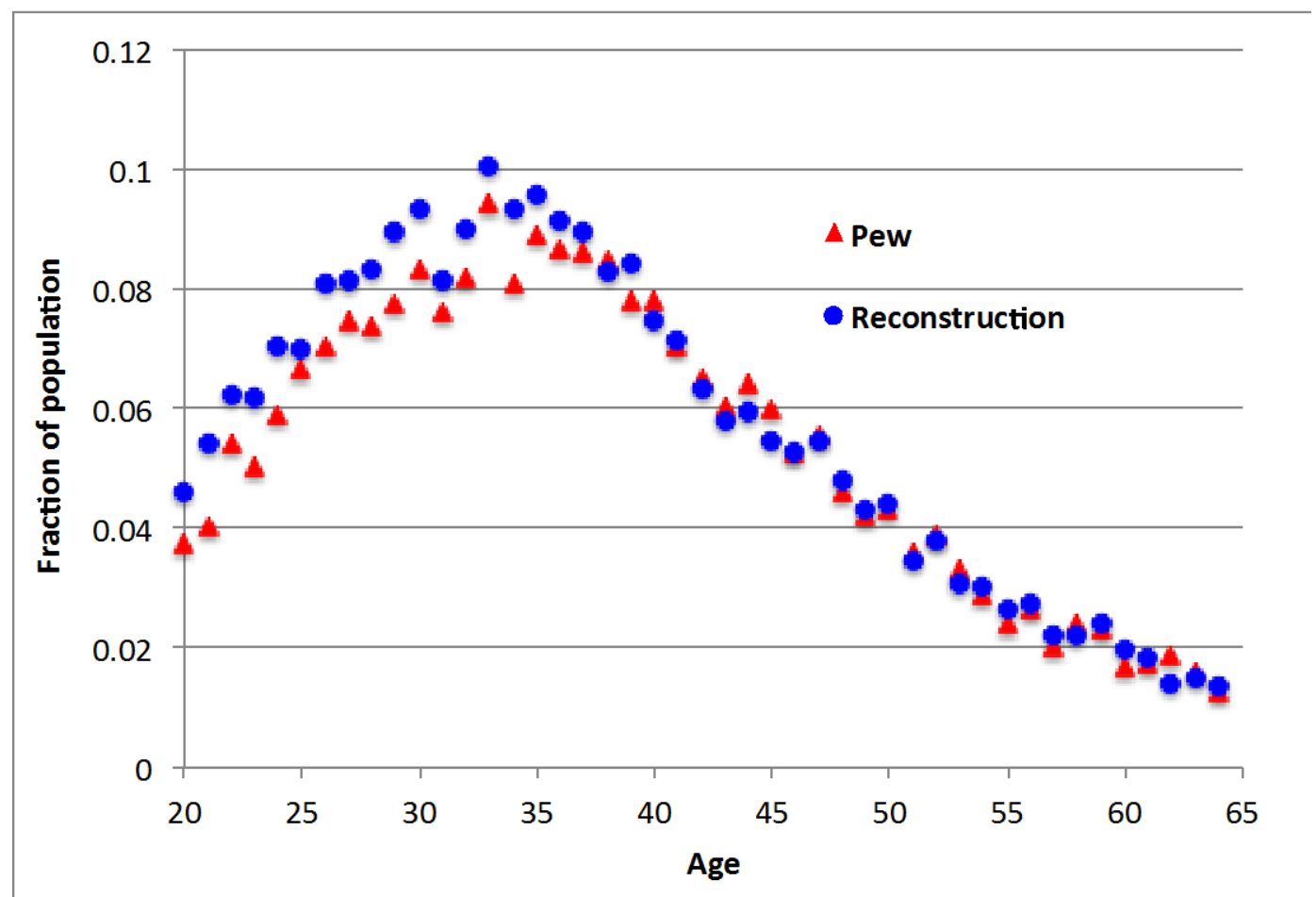

Notes: The figure calculates the percent of the population (at a particular age) that is foreign-born and is classified as undocumented using either the "likely unauthorized" status indicator created by Jeffrey Passel and colleagues at the Pew Research Center or my reconstruction of the undocumented status indicator (see text for details). 
Figure 3. Predicted age-employment profiles in Pew CPS-ASEC files, 2012-2013

\section{A. Men}

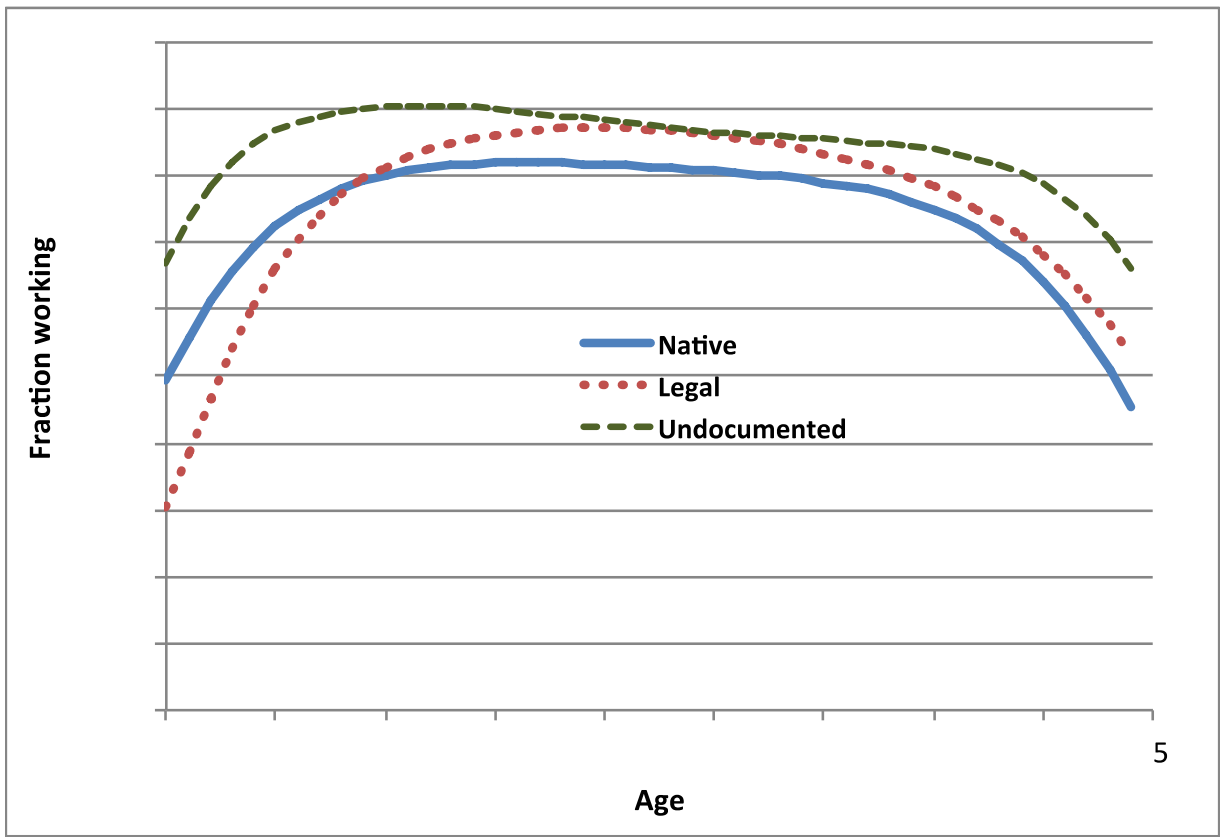

\section{B. Women}

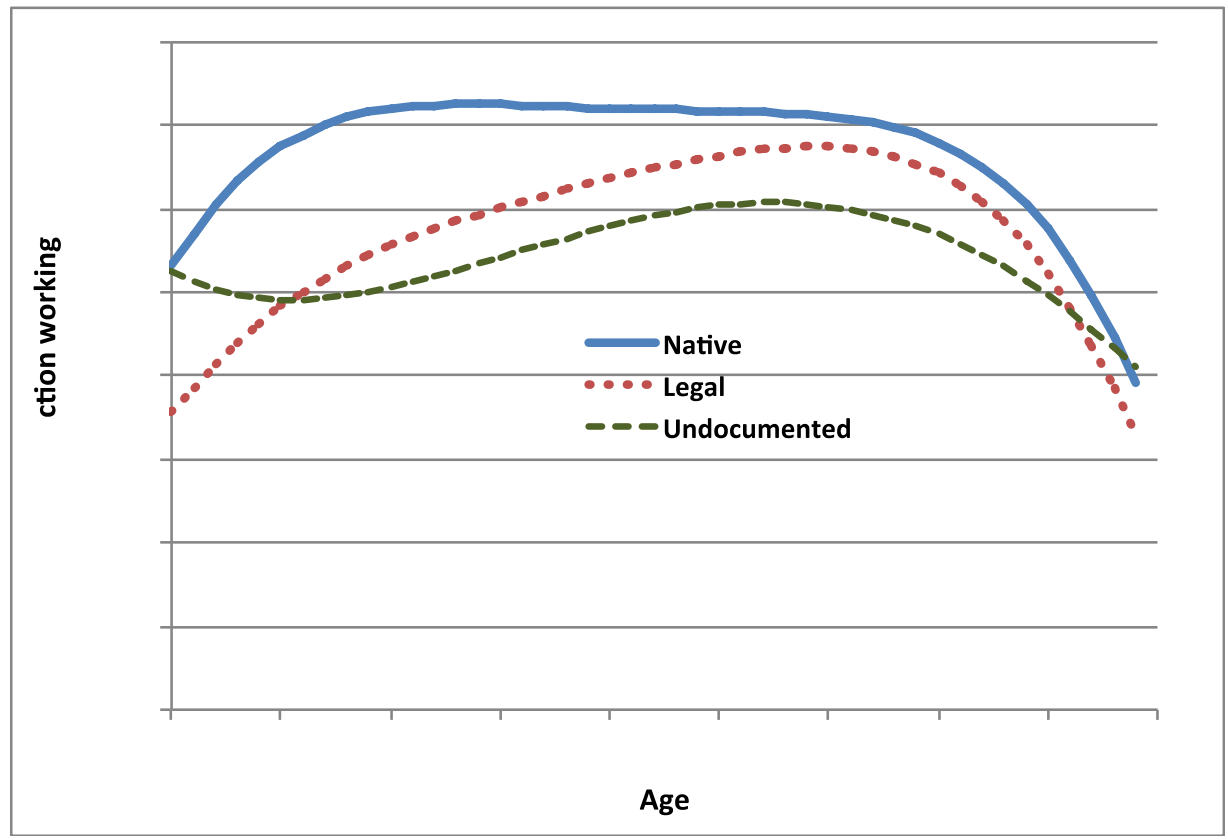

Notes: The predicted age-employment profiles are obtained from a logit regression of the probability that a person works during the CPS reference week on age (entered as a fourth-order polynomial), using the pooled 2012-2013 CPS-ASEC files created by the Pew Research Center. 
Figure 4. Predicted age-employment profiles in reconstructed CPS-ASEC files, 2012-2013

\section{A. Men}

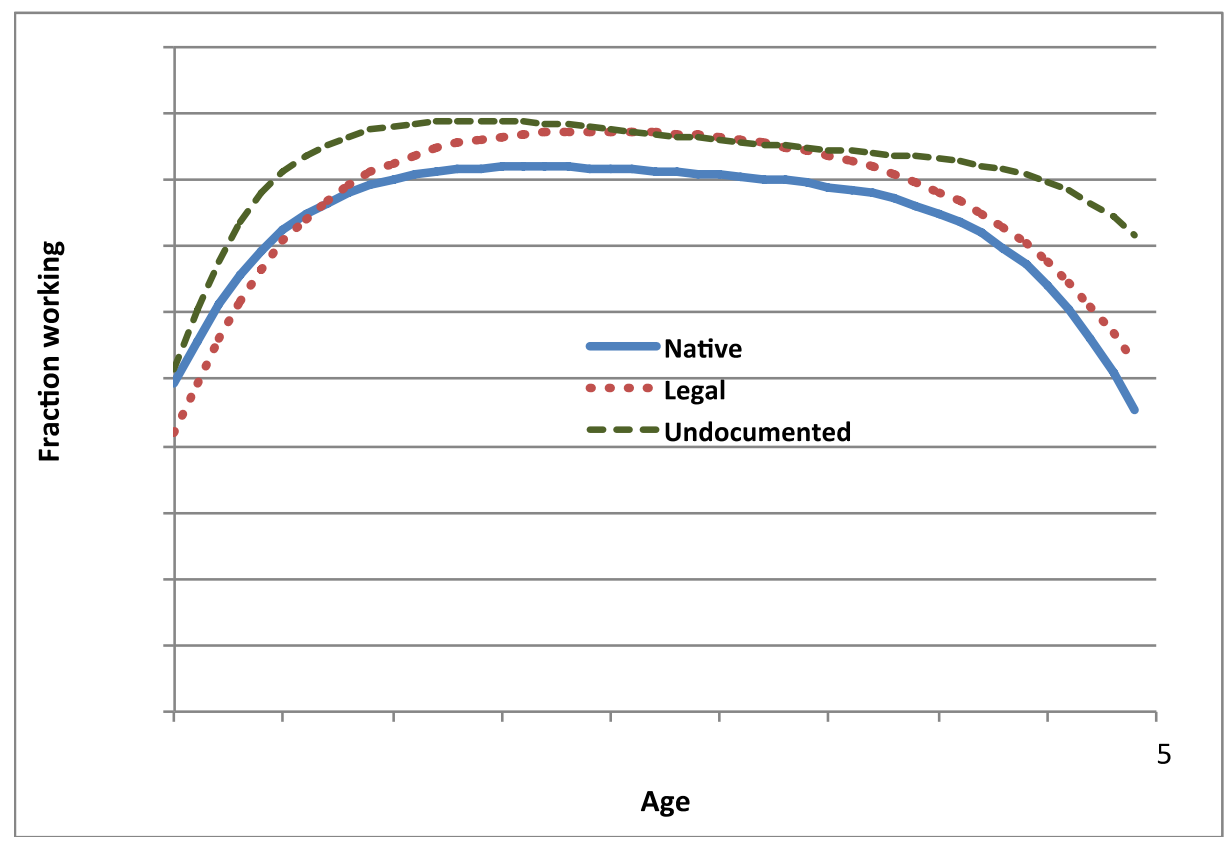

\section{B. Women}

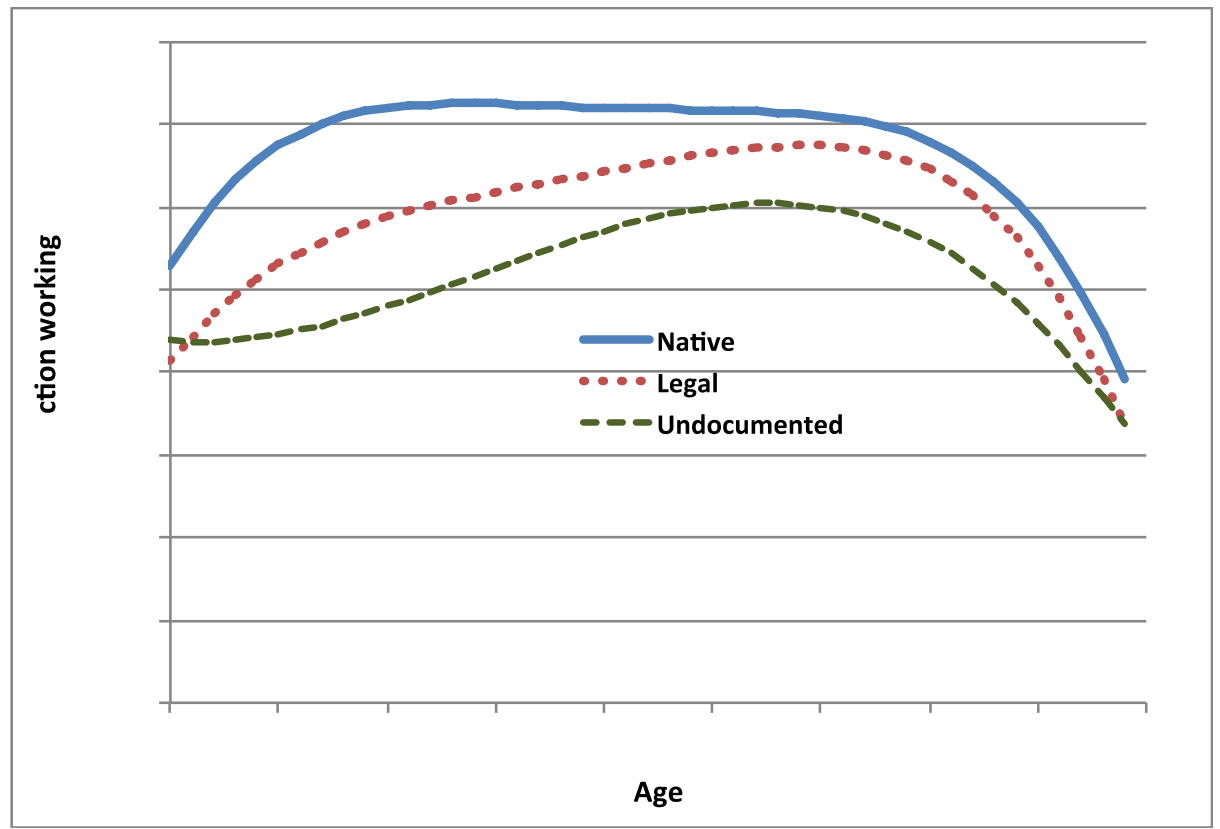

Notes: The predicted age-employment profiles are obtained from a logit regression of the probability that a person works during the CPS reference week on age (entered as a fourth-order polynomial), using the pooled 2012-2013 CPS-ASEC files that contain my reconstruction of the undocumented status indicator. 
Figure 5. Predicted age-employment profiles in Pew CPS-ASEC files, 2012-2013 (adjusted for education)

\section{A. Men}

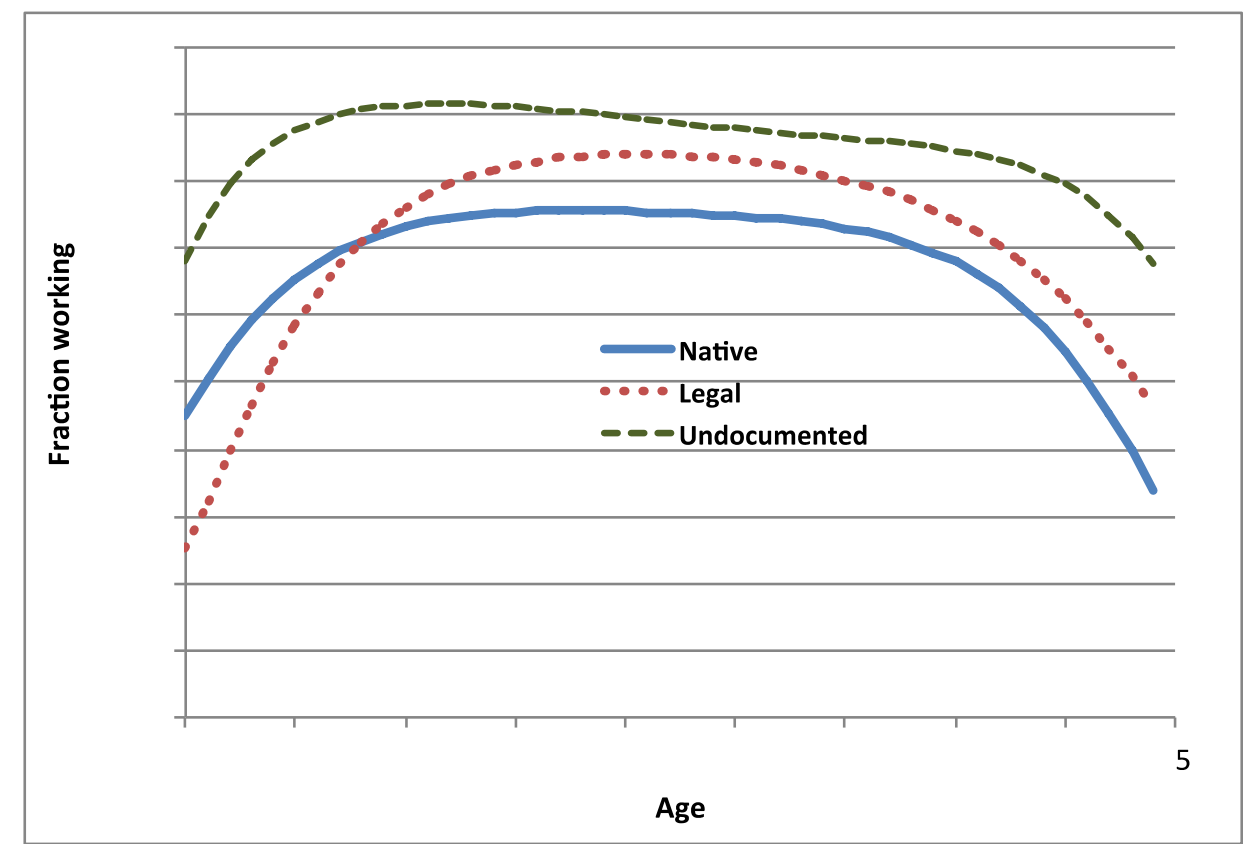

\section{B. Women}

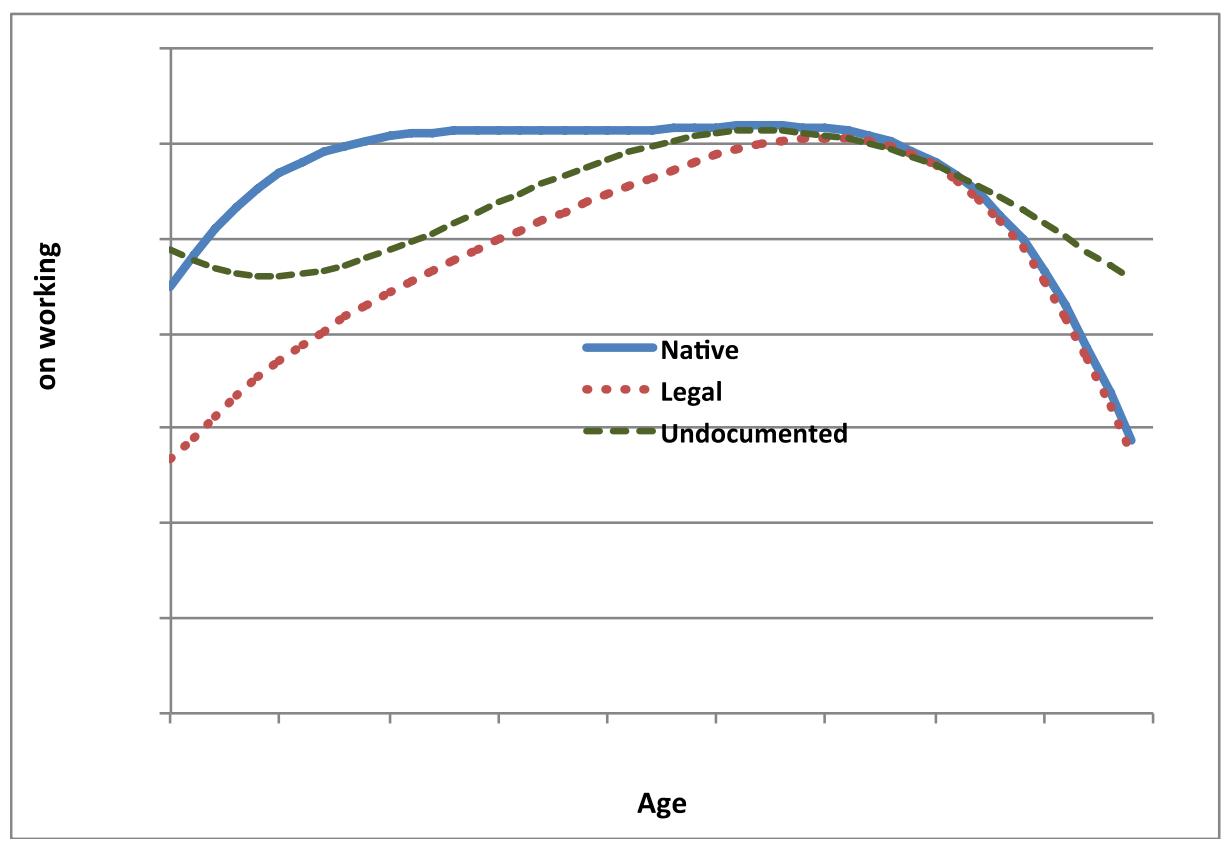

Notes: The predicted age-employment profiles are obtained from a logit regression of the probability that a person works during the CPS reference week on age (entered as a fourth-order polynomial) and a vector of fixed effects indicating the person's educational attainment, using the pooled 2012-2013 CPS-ASEC files created by the Pew Research Center. 
Figure 6. Trends in labor supply for men, 1994-2014

\section{A. Raw Data}

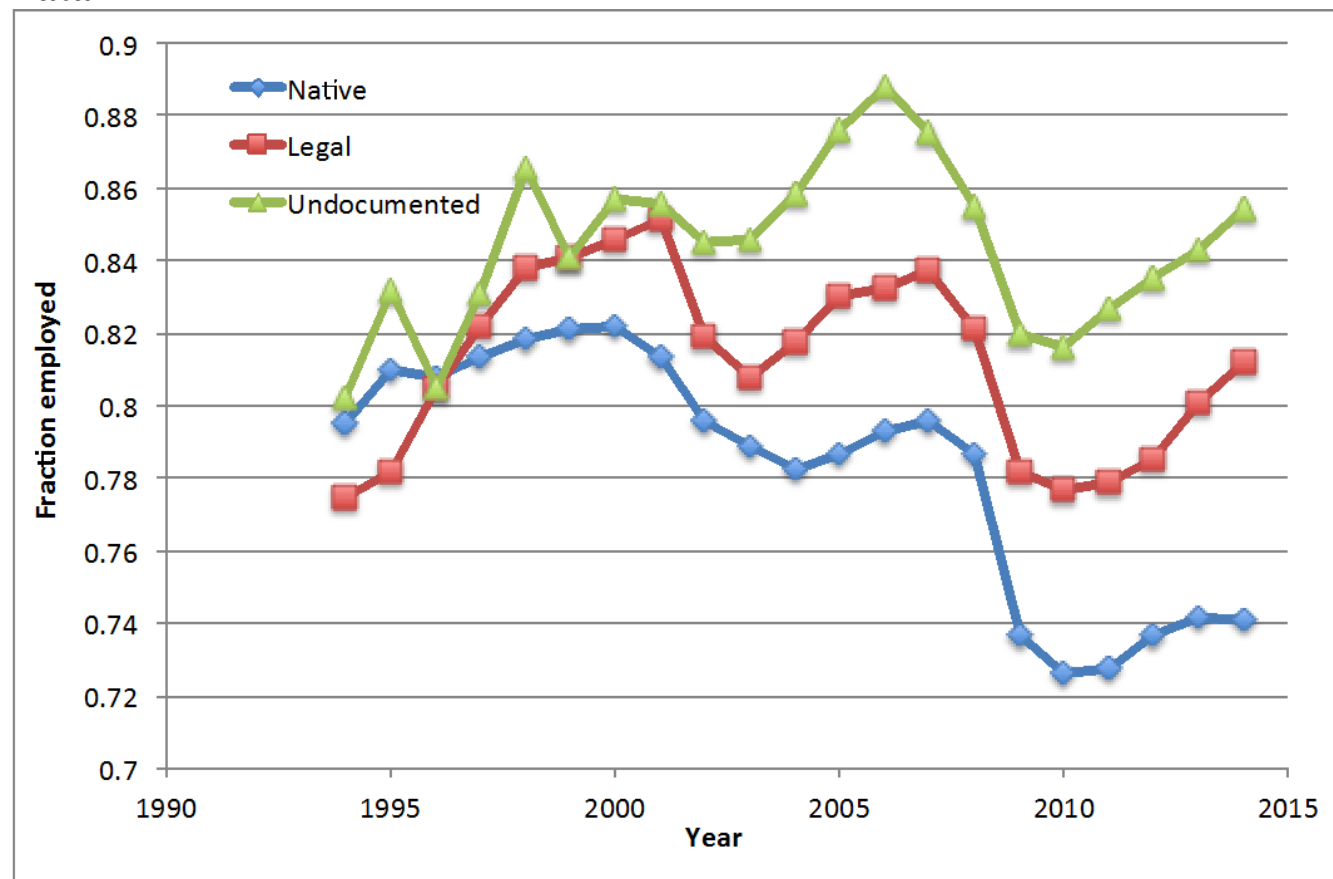

\section{B. Netting out year effects}

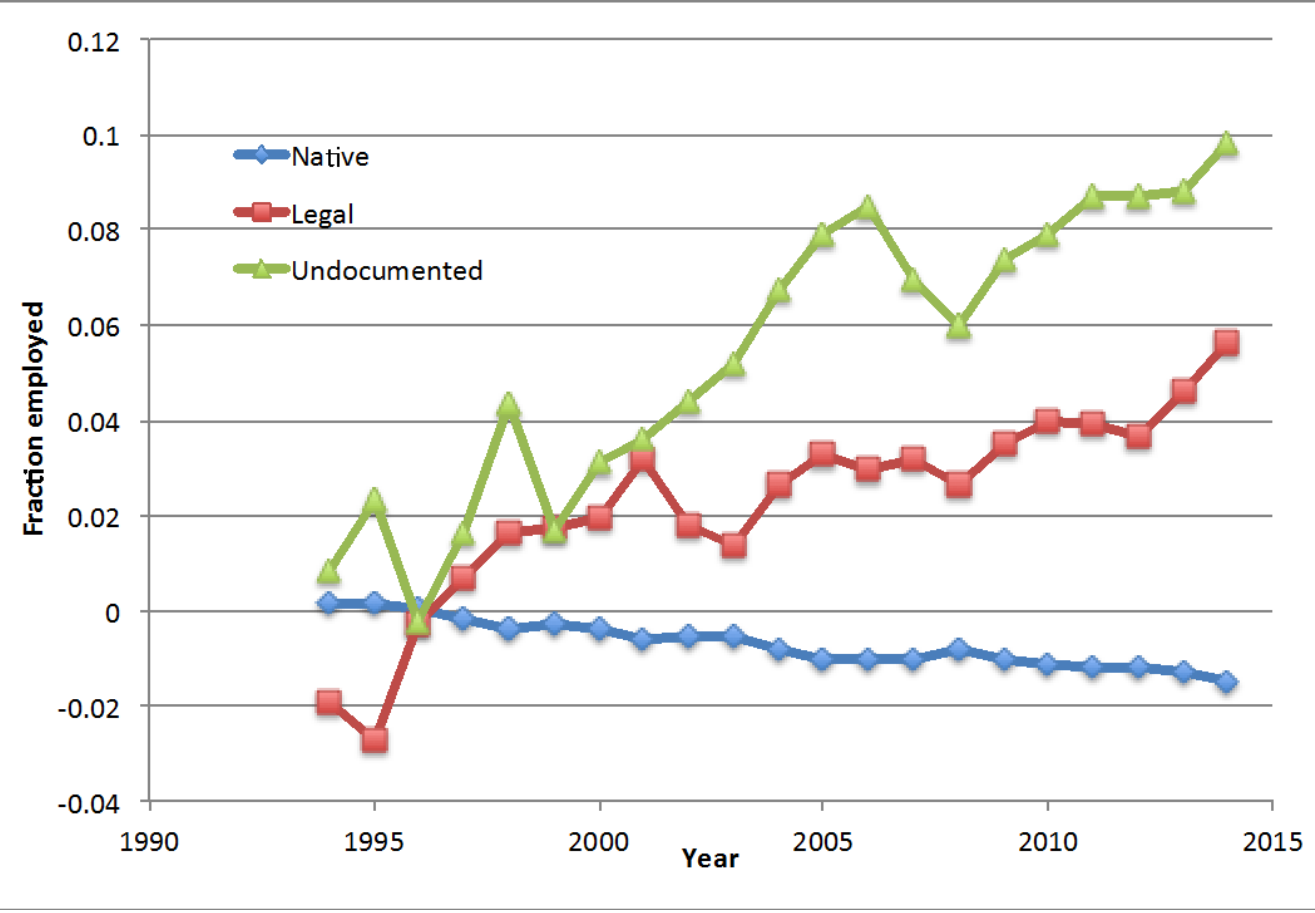

Notes: The figure illustrates the trend in the probability that a person works during the CPS reference week, using the 1994-2014 CPS-ASEC files that contain my reconstruction of the undocumented status indicator. 
Figure 7. Trends in labor supply for women, 1994-2014

\section{A. Raw data}

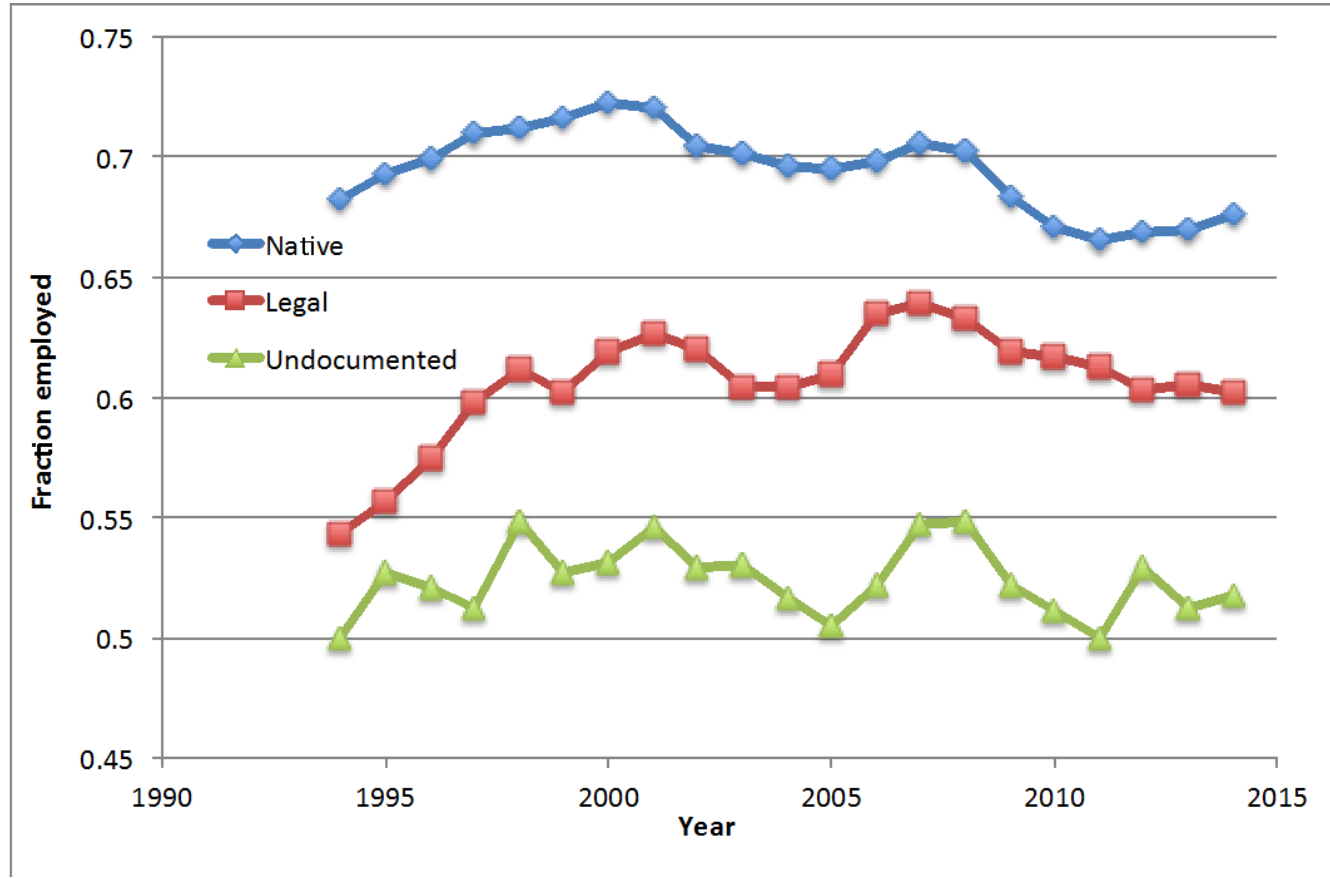

\section{B. Netting out year effects}

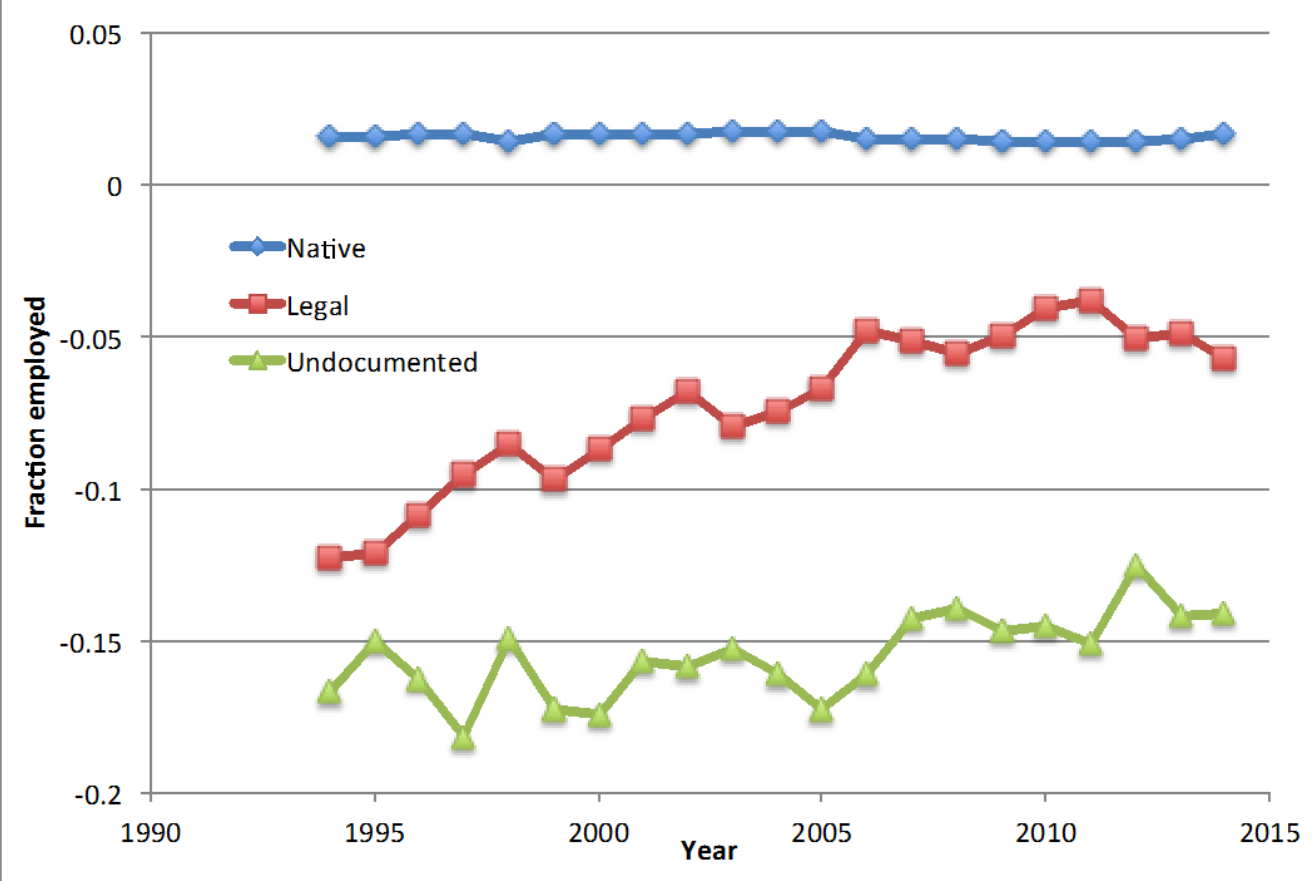

Notes: The figure illustrates the trend in the probability that a person works during the CPS reference week, using the 1994-2014 CPS-ASEC files that contain my reconstruction of the undocumented status indicator. 
Figure 8. Relation between hours of work and wages for men (by skill group and year)

\section{A. Natives}

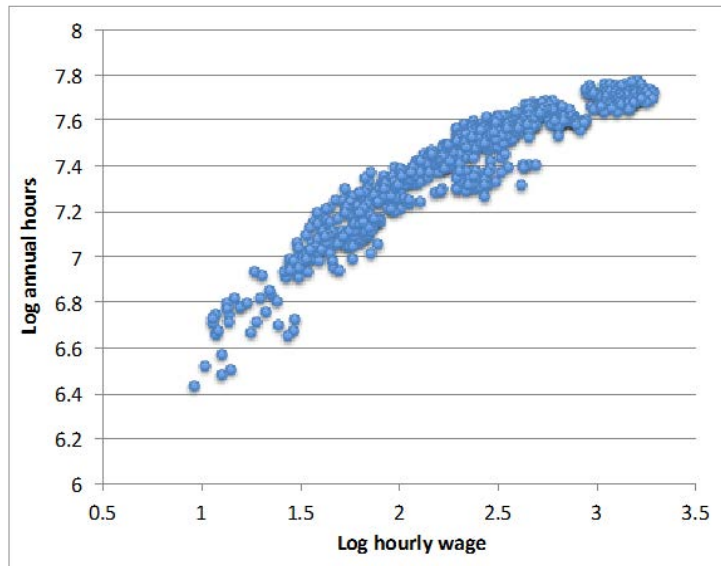

\section{B. Legal immigrants}

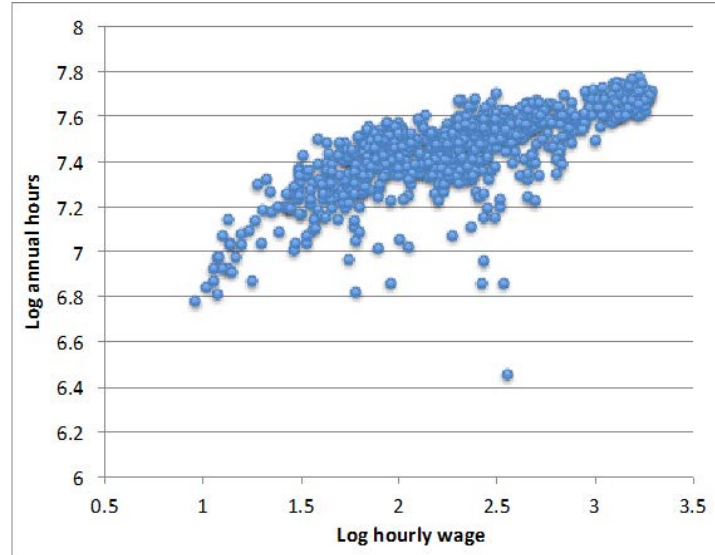

\section{Undocumented immigrants}

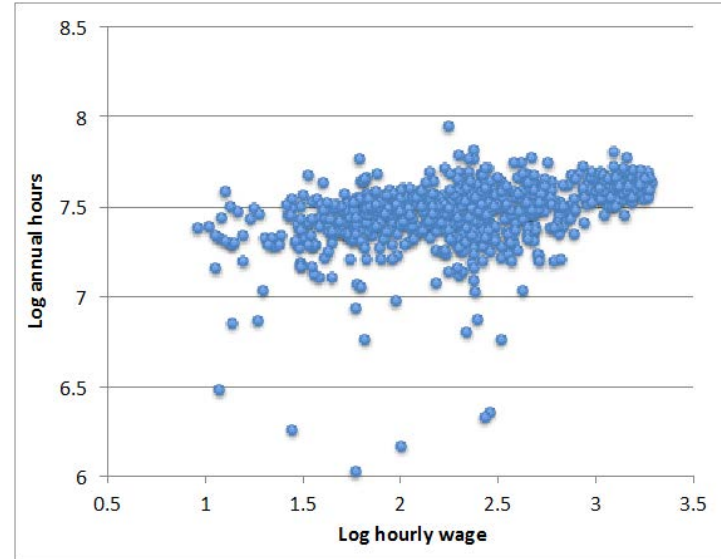

Notes: The scatter diagrams show the relation between the log of average annual hours worked (including nonworkers) and the log hourly wage of a particular age-education-year group , using the 1994-2014 CPS-ASEC files that contain my reconstruction of the undocumented status indicator. 
Table 1. Summary statistics in pooled 2012-2013 CPS-ASEC files

A. Pew CPS files

Percent of population

Percent male

Average age

Education:

High school dropouts

High school graduates

Some college

College graduates

State of residence:

California

New York

Texas

Employment rate

Men

Women

Sample size

B. Reconstruction of undocumented status indicator

Percent of population

Percent male

Average age

Education:

HS dropouts

Hs graduates

Some college

College graduates

State of residence:

California

New York

Texas

Employment rate

Men

Women

Sample size

\begin{tabular}{ccc} 
Legal & $\begin{array}{c}\text { Undocumented } \\
\text { immigrants }\end{array}$ \\
\hline
\end{tabular}

82.2

12.4

5.4

48.9

48.2

54.3

41.7

42.4

37.6

7.1

19.2

42.0

29.3

24.0

28.8

32.7

21.0

13.2

30.9

35.8

16.0

9.7

26.7

22.2

5.6

11.8

6.9

7.7

9.5

14.7

73.9

77.8

86.6

66.9

58.7

54.6

193,417

42,047

18,077

82.9

11.5

5.7

48.9

41.7

46.8

55.9

43.3

37.6

7.1

19.9

39.5

29.3

25.2

26.9

32.7

21.2

13.5

30.9

33.8

20.1

9.7

26.2

23.6

5.6

11.6

7.5

7.8

9.3

14.8

73.9

79.2

83.9

66.9

60.4

52.0

191,768

28,074

13,566

Notes: The summary statistics are calculated in the sample of persons aged 20-64. 
Table 2. Differences in labor supply in pooled 2012-2013 CPS-ASEC files

\begin{tabular}{|c|c|c|c|c|}
\hline \multirow{3}{*}{$\begin{array}{l}\text { Regression specification: } \\
\text { A. Men }\end{array}$} & \multicolumn{2}{|c|}{ Pew files } & \multicolumn{2}{|c|}{ Reconstructed files } \\
\hline & \multirow[t]{2}{*}{$\begin{array}{c}\text { Legal } \\
\text { immigrants }\end{array}$} & $\begin{array}{l}\text { Undocumented } \\
\text { immigrants } \\
\end{array}$ & $\begin{array}{c}\text { Legal } \\
\text { immigrants }\end{array}$ & $\begin{array}{c}\text { Undocumented } \\
\text { immigrants }\end{array}$ \\
\hline & & & & \\
\hline \multirow[t]{2}{*}{ No controls } & .039 & .127 & .054 & .100 \\
\hline & $(.004)$ & $(.005)$ & $(.004)$ & $(.005)$ \\
\hline \multirow[t]{2}{*}{ Adds age } & .023 & .100 & .037 & .075 \\
\hline & $(.004)$ & $(.005)$ & $(.004)$ & $(.005)$ \\
\hline \multirow[t]{2}{*}{ Adds age, education } & .034 & .173 & .052 & .138 \\
\hline & $(.004)$ & $(.005)$ & $(.004)$ & $(.005)$ \\
\hline \multirow{2}{*}{$\begin{array}{l}\text { Adds age, education, } \\
\text { geography }\end{array}$} & .041 & .174 & .060 & .140 \\
\hline & $(.007)$ & $(.001)$ & $(.004)$ & $(.005)$ \\
\hline \multicolumn{5}{|l|}{ B. Women } \\
\hline \multirow[t]{2}{*}{ No controls } & -.082 & -.122 & -.064 & -.148 \\
\hline & $(.004)$ & $(.006)$ & $(.004)$ & $(.006)$ \\
\hline \multirow{2}{*}{ Adds age } & -.092 & -.144 & -.075 & -.168 \\
\hline & $(.004)$ & $(.006)$ & $(.004)$ & $(.006)$ \\
\hline \multirow{2}{*}{ Adds age, education } & -.066 & -.040 & -.045 & -.076 \\
\hline & $(.004)$ & $(.006)$ & $(.004)$ & $(.006)$ \\
\hline \multirow{2}{*}{$\begin{array}{l}\text { Adds age, education, } \\
\text { geography }\end{array}$} & -.064 & -.041 & -.042 & -.074 \\
\hline & $(.004)$ & $(.006)$ & $(.004)$ & $(.006)$ \\
\hline \multicolumn{5}{|c|}{$\begin{array}{l}\text { Notes: Standard errors are reported in parentheses. The dependent variable indicates if the person worked during the } \\
\text { CPS reference week. The regressions control for age by including a vector of fixed effects indicating the person's } \\
\text { age in five-year bands (20-24, 25-29, and so on). The regression controls for educational attainment by including a } \\
\text { vector of fixed effects indicating if the person is a high school dropout, a high school graduate, has some college, or } \\
\text { is a college graduate. The controls for geography include a vector of fixed effects indicating the person's state of } \\
\text { residence and a dummy variable indicating if the person lives in a metropolitan area. All regressions also include a } \\
\text { dummy variable indicating if the observation was drawn from the } 2013 \text { cross-section. The male (female) regressions } \\
\text { estimated in the Pew files have } 122,520(131,014) \text { observations. The male (female) regressions estimated in the } \\
\text { reconstructed files have } 112,127(121,281) \text { observations. }\end{array}$} \\
\hline
\end{tabular}




\section{Table 3. Determinants of differential trends in labor supply (Pooled 1994-2014 ASEC-CPS files)}

\begin{tabular}{llll}
\multicolumn{4}{c}{ Specification } \\
\hline$(1)$ & $(2)$ & $(3)$ & $(4)$ \\
\hline
\end{tabular}

A. Men

Trend $\times$ legal immigrant

Trend $\times$ undocumented

B. Women

Trend $\times$ legal immigrant

Trend $\times$ undocumented

.0024
$(.0007)$
.0033

(.0015)

.0017
$(.0005)$
.0035
$(.0010)$

.0020

$(.0004)$

.0051

(.0010)
.0018

(.0004)

.0047

(.0010)

Fixed effects included:

Year
Skill
Skill-year
State-year

Yes
No
No
No

.0020

(.0004)

.0017

(.0011)

.0015

(.0003)

.0012

(.0010)
(.0010)

Notes: Standard errors are reported in parentheses and are clustered at the skill group level. The "trend" variable is a linear trend set to 1 in 1994. The skill fixed effects indicates the age-education group that the worker belongs to. The skill-year fixed effects interact the age-education fixed effects with year fixed effects. The state-year fixed effects interact state of residence fixed effects with year fixed effects. The regressions estimated in the male sample have 1,719,623 observations; the regressions estimated in the female sample have 1,828,025 observations. 


\section{Table 4. Estimates of labor supply elasticities (using 1994-2014 reconstructed CPS-ASEC files)}

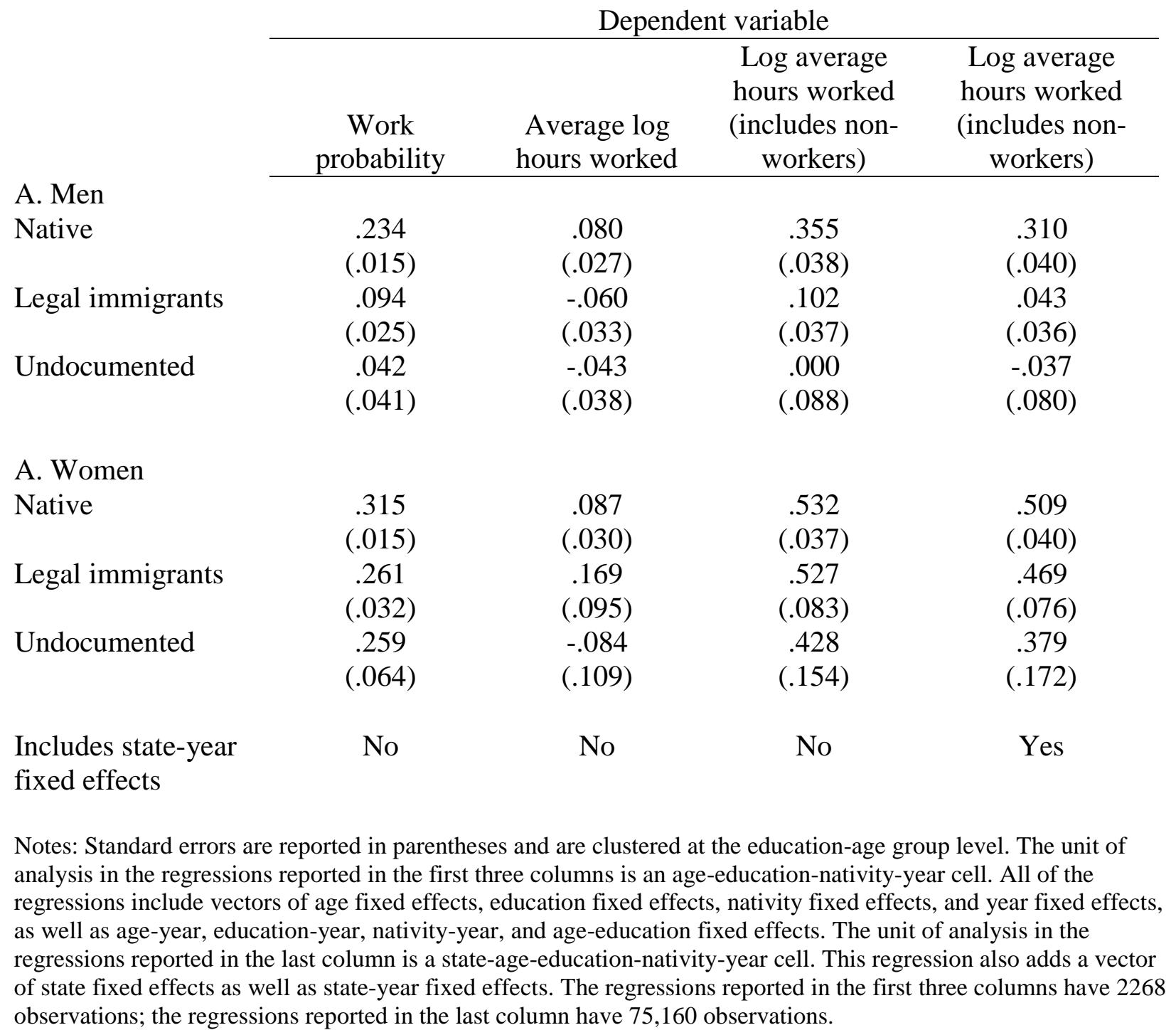


Table 5. Labor supply elasticities in Pew and in reconstructed data (Pooled 2012-2013 CPS files)

Dependent variable

\begin{tabular}{ccc}
\hline $\begin{array}{c}\text { Work } \\
\text { probability }\end{array}$ & $\begin{array}{c}\text { Average log hours } \\
\text { worked }\end{array}$ & $\begin{array}{c}\text { Log average hours worked } \\
\text { (includes non-workers) }\end{array}$ \\
\hline
\end{tabular}

Pew ASEC files

A. Men

Native

.281

.107

.395

(.036)

(.076)

(.055)

Legal

.133

.019

.138

(.032)

(.076)

(.047)

Undocumented

.087

$-.020$

.046

(.032)

(.079)

(.051)

B. Women

Native

.318

.193

(.112)

.563

(.034)

.125

(.092)

Legal

.235

(.110)

.419

(.039)

.040

(.088)

Undocumented

.169

(.112)

.260

(.089)

Reconstructed ASEC files

C. Men

Native

.281

.098

.419

(.038)

(.083)

(.069)

Legal

.169

.038

.226

(.034)

(.084)

(.050)

Undocumented

.062

$-.048$

.038

(.034)

(.086)

(.058)

D. Women

Native

.317

.202

(.038)

(.114)

.541

Legal

.257

(.044)

.157

(.085)

(.109)

.448

.102

.034

(.087)

Undocumented

(.051)

(.118)

.122

(.096)

Notes: Standard errors are reported in parentheses and are clustered at the education-age group level. The unit of analysis in the regressions is an age-education-nativity-year cell. All of the regressions include vectors of ageeducation fixed effects, nativity fixed effects, and year fixed effects. The regressions have 216 observations. 